\title{
International Investment Law and Arbitration: A Conceptual Framework
}

\author{
Rob Howse"
}

\section{Introduction}

Today, arguably, investor-state dispute settlement (ISDS) has become the most controversial form of international litigation (very recently rivalled perhaps by the International Criminal Court, which is facing a stark legitimacy challenge from a number of African states). Arbitration under the International Centre for the Settlement of Investment Disputes (ICSID) or UNCITRAL (The United Nations Commission on International Trade Law) allows an investor to sue a host state before an ad hoc arbitral tribunal for violations of bilateral investment treaties (BITs) or trade and investment agreements (e.g., the North American Free Trade Agreement (NAFTA)). ${ }^{1}$ If successful, the investor can enforce a monetary award against the host state in ordinary courts around the world. This regime has, more or less plausibly, been painted as a network of secret or "shadow" courts dominated by a clique of elite arbitrators motivated not by justice but by personal wealth acquisition, a system where multinational corporations unleash blue chip law firms on some of the poorest countries in the world, forcing multimillion dollar settlements or winning awards that are

* Professor at the University of New York.

1 The treaty norms most frequently invoked in these disputes are the requirement of full market value compensation for expropriation, fair and equitable treatment (which has been interpreted to mean most narrowly protection from extreme egregious or shocking conduct of the state and most expansively the entitlement of the investor to a stable transparent legal and regulatory framework), and national treatment and most-favoured nation (MFN) treatment) (non-discrimination with respect to nationality). These norms are present in almost all the treaty instruments that provide for investor protection even though the wording differs from treaty to treaty as do the exceptions or limitations clauses. Sometimes these agreements also contain a so-called "umbrella clause", which may elevate breach of a contract between the investor and the host state, or of certain other kinds of commitments by the host state, into a breach of the treaty. What effect such "umbrella clauses" have, has been the subject of highly inconsistent rulings among different arbitral tribunals. 
even larger, sometimes more than an impoverished nation's entire annual budget for health, education and public security. ${ }^{2}$ The fear of such pay-outs has understandably had a chill effect on legitimate government regulation in many countries; inconsistently interpreted by arbitrators in different cases, the general norms in investment treaties have been read to go far beyond compensation for takings that aim to extract rents from investors and are likely inefficient, extending to regulatory changes that respond to many valid policy concerns but a negative economic impact on some particular foreign investor.

Such criticisms have made headlines and influenced debates about globalization at the highest political levels in the United States, and Europe. In a letter to Members of Congress, over 200 academics in law and economics, including such distinguished scholars as Laurence Tribe and Joseph Stiglitz, made the following critique of ISDS:

Through ISDS, the federal government gives foreign investors and foreign investors alone the ability to bypass that robust, nuanced, and democratically responsive legal framework. Foreign investors are able to frame questions of domestic constitutional and administrative law as treaty claims, and take those claims to a panel of private international arbitrators, circumventing local, state or federal domestic administrative bodies and courts. Freed from fundamental rules of domestic procedural and substantive law that would have otherwise governed their lawsuits against the government, foreign corporations can succeed in lawsuits before ISDS tribunals even when domestic law would have clearly led to the rejection of those companies' claims. Corporations are even able to relitigate cases they have already lost in domestic courts. It is ISDS arbitrators, not domestic courts, who are ultimately able to determine the bounds of proper administrative, legislative, and judicial conduct. This system undermines the important roles of our domestic and democratic institutions, threatens domestic sovereignty, and weakens the rule of law. In addition to these fundamental flaws that arise from a parallel and privileged set of legal rights and recourse for foreign economic actors, there are various flaws in the way ISDS

2 See e.g. P. Eberhardt \& C. Olivet, 'Profiting from Injustice: How Law Firms, Arbitrators and Financiers are Fuelling an Investment Arbitration Boom' (2012) available at https://corporateeurope.org/international-trade/2012/11/profiting-injustice (last visited 6 December 2018); C. Hambly, 'Secrets of a Global Super Court' (six part series) (2016), available at https://www.buzzfeed.com/chrishamby/super-court (last visited 6 December 2018). 
proceedings are meant to be conducted in the TPP. In short, ISDS lacks many of the basic protections and procedures of the justice system normally available in a court of law. There are no mechanisms for domestic citizens or entities affected by ISDS cases to intervene in or meaningfully participate in the disputes; there is no appeals process and therefore no way of addressing errors of law or fact made in arbitral decisions; and there is no oversight or accountability of the private lawyers who serve as arbitrators, many of whom rotate between being arbitrators and bringing cases for corporations against governments. Codes of judicial conduct that bind the domestic judiciary do not apply to arbitrators in ISDS cases. ${ }^{3}$

In September 2015, in the context of the negotiations between the European Union and the United States on the Trans-Atlantic Trade and Investment Partnership (TTIP), the European Commission proposed to address public outrage at investor-state arbitration through inventing an alternative judicial system for the settlement of investment disputes. The judicial system would initially be incorporated (instead of arbitration) in bilateral agreements of the EU such as TTIP, but eventually would be replaced by a multilateral tribunal for the settlement of investment disputes.

The European Commission proposal has its origins in an on-line consultation the EU undertook with respect to investor protection in the TTIP; the consultation produced an astonishing number of responses-something like 150,000-with a huge number of them indicating hostility to investor-state dispute settlement. In July 2015, in its guidance to TTIP negotiators, the European Parliament recommended that under TTIP, investment disputes be settled by a standing judicial body, rather than conventional methods of investor-state arbitration. ${ }^{4}$ The proposal, which has now been adopted by the Commission for future investment-related agreements as well as in the EU's recent accords with Canada and Viet Nam, is a comprehensive response to the challenge of the Parliament and European civil society, producing a detailed blueprint for an alternative judicial system of ISDS. More recently, the EU, as will be discussed below, has worked with

3 This letter is available at http://www.afj.org/press-room/press-releases/more-than-10 0-legal-scholars-call-on-congress-administration-to-protect-democracy-and-sovereign ty-in-u-s-trade-deals (last visited 6 December 2018).

4 European Parliament Resolution containing the European Parliament's Recommendations to the European Commission on the Negotiations for the Transatlantic Trade and Investment Partnership, 8 July 2015 (2014/2228 (INI). 
Canada to develop a multilateral investment court into which these bilateral judicial arrangements could be merged or that would supersede them.

While, as Poulsen and Aisbett document, ${ }^{5}$ many developing countries had already pushed back on ISDS (for example, signing fewer BITs or even in some cases denouncing them), in developed countries, until the EU proposal, the ISDS insider community had been able to marginalize the critics in serious policy discussions, disparaging them as outsiders who do not really understand how and why investor-state arbitration works. The rejection of investor-state arbitration by the European Parliament and Commission has conferred unprecedented political legitimacy on the critics of the existing system of ISDS, even if some of the critics have responded that the EU proposals do not really answer their objections. The Commission and Parliament speak for a significant number of countries, some of whom have traditionally been among the largest users of ISDS. When EU Commissioner for Trade Cecilia Malmstrom introduced the Commission proposal, she stated with bluntness its underlying foundation: a "fundamental and widespread lack of trust" in the existing ISDS system. ${ }^{6}$ After such a statement, at least in the EU, it will be very difficult to retreat to that system, whatever pressures come from the arbitration bar and similar quarters. Indeed, far from retreat, the EU has already, as noted, incorporated the judicial model into agreements with Canada and Viet Nam and may soon do so with Singapore and Japan, and, with Canada, the EU is now taking the initiative to transform the judicial model in these agreements into a multilateral investment court. This project has already attracted the interest of dozens of states, and initial consultations have been held in Geneva and more recently at the 2017 World Economic Forum in Davos. ${ }^{7}$

Some criticisms of the existing ISDS system do not hold water. For instance, there is no real evidence that arbitrators are systematically biased to-

5 L. Poulsen \& E. Aisbett, When the Claim Hits: Bilateral Investment Treaties and Bounded Rational Learning, 65 World Politics (2013), 273.

6 C. Malmström, 'Proposing an Investment Court System' (2015), available at https:// ec.europa.eu/commission/2014-2019/malmstrom/blog/proposing-investment-courtsystem_en (last visited 6 December 2018).

7 See European Commission \& Government of Canada, 'The Case for Creating a Multilateral Investment Dispute Settlement Mechanism, Informal Ministerial Meeting, World Economic Forum, Davos, Switzerland' (2017), available at http://tr ade.ec.europa.eu/doclib/docs/2017/january/tradoc_155264.pdf (last visited 6 December 2018). 
ward investors, ${ }^{8}$ and indeed the statistics show that host states win a very large number of disputes. ${ }^{9}$ While there have been some cases where investors have tried to use or abuse ISDS to attack general public policies (such as Methanex), this strategy has met with little success; Philip Morris's attack on Australia's tobacco regulations is a recent further example of the failure of the strategy. On the other hand, critics point out, the results in litigated cases do not exhaust the impact of ISDS on regulatory autonomy; the threat of bringing a claim may, especially in the case of developing countries, itself lead to regulatory chill. There is increasingly evidence of this, at least of an anecdotal kind, albeit presented in rather sensationalist terms in the popular media; as discussed below, where host states have settled claims to avoid litigation, in essentially all cases where public information is available, the settlement involved very substantial monetary payments, or regulatory accommodations in favour of the investor. Lack of doctrinal consistency among tribunals, and the broad sweep in the way that some tribunals have stated their reasons while others have ruled narrowly on as fact-specific basis as possible with sparse legal reasoning, lead to uncertainty about the space that states have to engage in legitimate regulation, even if results in individual cases rarely amount to the radical attack on regulatory autonomy that is often claimed by critics.

The aim of this essay is to develop a conceptual framework or model that could inform debate over reform proposals on ISDS as well as to evaluate critiques and defences of the existing system of investor protection in international law. Unlike the case of trade law, until very recently there was very little theoretical or empirical work in economics that could inform a rigorous scholarly approach. Bown and Horn note (writing at the end of 2015): "It is...no exaggeration to say that Economics has paid little attention to the more than 3000 IIAs that are currently in force." ${ }^{10}$ Two exceptions are the empirical literature that addresses whether and how developing countries benefit from FDI, as well as that on the important question

8 A recent empirical study found that arbitrators' personal political orientation and experiences do influence their decision-making, but that there is no general tendency to pro-investor (pro-claimant) bias. See M. Waibel \& R. Wu, Are Arbitrators Political?: Evidence from International Investment Arbitration (2017) (unpublished manuscript) (on file with author). See also A. Shtreznev, Detecting Bias in International Investment Arbitration, (2016), paper presented at International Studies Association Annual Meeting, Atlanta, GA (March 17-22, 2016).

9 S.D. Franck \& L. E. Wylie, Predicting Outcomes in Investment Treaty Arbitration, 65 Duke Law Journal (2015), 459.

10 C. Bown \& H. Horn, Investment Protection in Regional Trade Agreements (2015), 4 (on file with author). 
of whether international legal protections increase the flow of inwardbound FDI, particularly in developing and transitional economies. While, as mentioned, historically the economic literature has been sparse, the recent significant scholarship of Emma Aisbett, Chad Bown, Henrik Horn, and various co-authors (Economics), Jonathan Bonnitcha (Law and Economics), Anne van Aaken (Law and Economics), Lauge Poulsen and Beth Simmons (Political Economy), Susan Franck and Michael Waibel (Empirical Legal Studies) enables a much more informed assessment of the rationales for investment agreements and different ISDS options. Finally it was Joseph Stiglitz who first led me to begin thinking critically about the investment regime.

The framework or model developed in this essay is intended to indicate the kind of scholarly agenda going forward that is likely to illuminate policy choices instead of reproducing arguments for set positions in a heated policy debate. I proceed as follows.

I begin with a historical overview of international law protection of foreign investors. This overview suggests that such protection has always been controversial, but that the controversies have shifted along different ideological, institutional, and geopolitical axes over time, sometimes focusing on substantive legal norms or even where they should be negotiated, and at other times on the proper forum for settling disputes. The historical perspective helps to understand why the current debate is so complex, and at times, confusing. Today's context for choosing options for protection of investors through international law is distinctive in many ways, yet the current debate often bears the assumptions from earlier controversies.

After the historical overview, I next disaggregate (the often not clearly or well distinguished) rationales for giving foreign investors special protections under international law in their dealings with host states. I consider such economic theory and empirical work that exists on foreign investment as well as political economy approaches, theories about bargaining between governments and firms (e.g., Laffont and Tirole ${ }^{11}$ ), and other relevant normative conceptions such as good governance, rule of law, and nondiscrimination. I attempt a rough or preliminary evaluation of the strength of the various rationales, in light of possible downsides that have been identified in the literature. This part of the paper in particular stands on the shoulders of Gus van Harten's 2010 paper, "Five Justifications for In-

11 JJ. Laffont \& J. Tirole, A Theory of Incentives in Procurement and Regulation (1993). 
vestment Treaties: A Critical Discussion." ${ }^{12}$ My articulation of the rationales is somewhat different from van Harten's, in part due to the way the scholarly debate has evolved since; van Harten did not have the benefit of a wealth of economics and political economy studies cited here that appeared after 2010, and I should say that he was particularly prescient in suggesting that a reasoned assessment of the rationales for treaty protection of investors would point to the replacement of ad hoc arbitration with a judicial model. This is the overall conclusion of this present study, with a strong preference for a multilateral judicial system.

In the section of the essay that follows the consideration of rationales, I examine to what extent the most common legal protections found in treaty instruments (compensation for expropriation, fair and equitable treatment (FET), and national treatment (NT) align well or poorly with the various rationales. I also bring in a couple of possible variations: 1 ) these norms are accompanied by an "umbrella clause" that may elevate contractual claims of the investor as well as non-contractual reliance-type claims on government representations into treaty claims; 2 ) the various investor protections are limited or balanced by a general public policy exception clause, like that in the General Agreement on Tariffs and Trade (GATT) and other agreements of the World Trade Organization (WTO), which allows the defendant state to argue that the challenged measures constitute policies necessary to achieve legitimate public policy purposes, while being maintained in a manner that is non-discriminatory, non-arbitrary, and consistent with the due process of law (the GATT general exceptions provision as interpreted by the WTO Appellate Body). ${ }^{13}$ In this stylized discussion, I bracket the question of how the norms in question are interpreted, and I assume as wide a range of readings as is indicated by the current system of ISDS where ad hoc arbitration without precedent or appeal has generated enormous inconsistencies in the way that general norms are understood, particularly fair and equitable treatment but also regulatory takings (often characterized as indirect expropriation). ${ }^{14}$

The third section examines what kind of dispute settlement is optimal based upon a given rationale and the kind of substantive norms that would

12 G. van Harten, Five Justifications for Investment Treaties: A Critical Discussion, 2 Trade, Law and Development (2010), 19.

13 Examples of such clauses are to be found in the model investment agreements of Canada and India.

14 S.D. Franck, The Legitimacy Crisis in Investment Treaty Arbitration: Privatizing Public International Law Through Inconsistent Decisions, 73 Fordham Law Review (2005), 1521. 
be well-matched to that rationale. Here I address (admittedly stylized) options: the existing system, assuming widely criticized features of it are largely preserved; state-to-state dispute settlement, which over history has been the predominate model for settling disputes in international economic relations (and where the most highly developed form is represented by the WTO dispute settlement system); the bilateral Investment Court System (ICS) as proposed by the EU and featured in CETA and the EU-Vietnam Agreement; a multilateral investment tribunal, along the lines that the EU and Canada are now taking the leadership to negotiate with a wide range of countries; such a tribunal might hear both state-to-state claims and investor-state claims, as well as provide standing to other actors affected by investment disputes, e.g., indigenous peoples, community groups, victims of human rights violations, and NGOs. ${ }^{15}$

My conclusion is that to the extent that any of the commonly stated rationales for the investment regime hold water, and the substantive norms of the regime fit with these rationales, a multilateral investment court is a superior forum to investor-state arbitration, or even bilateral adjudication; moreover, on some rationales, the availability not just of investor claims but of standing for other stakeholders and of state-to-state dispute settlement in the multilateral court may be of key importance.

\section{Historical Overview of International Law and Investor Protection ${ }^{16}$}

The first uses of international law as a tool of investor protection stem from efforts of capital-exporting states in the $19^{\text {th }}$ century and early $20^{\text {th }}$ century to use the customary law of diplomatic protection of aliens primarily against states in the global South. A minimum standard of treatment was asserted, including access to justice and protection against expropriation, and it was sometimes enforced by gunboat diplomacy or the threat

15 Supra note 7.

16 This overview draws considerably from A. Newcombe \& L. Paradell, Historical Development of Investment Treaty Law, in A. Newcombe \& L. Paradell, Law and Practice of Investment Treaties: Standards of Treatment (2009), and M. Sornarajah, The International Law on Foreign Investment (2010). However, the most rigorous scholarly account of the origins of the investment regime is K. Miles, The Origins of International Investment Law: Empire, Environment and the Safeguarding of Capital (2013). 
thereof. ${ }^{17}$ To forestall gunboat diplomacy, and otherwise to depoliticize these disputes, Southern countries agreed not infrequently to submit to disputes about diplomatic protection to state-to-state arbitral commissions. However, the legitimacy of capital-exporting countries' demands for special international law protection of investments continued to be challenged as reflected in the Calvo Doctrine, initially developed by the Argentine jurist Carlos Calvo in the second half of the $19^{\text {th }}$ century. The Calvo Doctrine holds that as matter of international law the obligation to foreign investors should be limited to non-discrimination. They should be entitled to legal protection equal to that of domestic investors, including access to justice in the domestic courts. (The one norm that attracts wide normative consensus among states and other stakeholders even today is in fact that of non-discrimination.)

With the Kellog-Briand Pact of 1928, the use of force as a means of enforcing diplomatic protection was finally off the table. Nevertheless, especially in the case of the United States in Latin America, political and diplomatic power would continue to be used for decades to protect US investments and to pressure or coerce the host states, regardless of international law; at the same time, however, through arbitration commissions and various (first world-dominated) international legal processes, the notions of an autonomous customary international law standard for treatment of aliens and compensation for expropriation became rather deeply entrenched in the international community. After the end of World War II and the start of the cold war as well as the process of decolonization, normative conflict broke out into the open again. At the United Nations, developing countries argued for a New International Economic Order to establish a just relationship between Northern and Southern Countries; they insisted on control over their natural resources and the right to nationalize, and challenged the notion that there should be an international standard for compensation of investment set at full market value. The United States spread its view of investor protection under international law through treaties of Friendship, Navigation and Commerce (FNC) that contained investor protection provisions. The Soviet Bloc countries ideologically rejected the protection of property and contract rights for private capital, although not closing the door to foreign investment as a means of dealing with problems like a lack of foreign exchange reserves, and bottlenecks in develop-

17 See generally C. Lipson, Standing Guard: Protecting Foreign Capital in the Nineteenth and Twentieth Centuries (1985). 
ment and technological progress produced by the pathologies of the Soviet economic system.

The creation of ICSID in the early 1960s was intended to depoliticize these conflicts over investment through investor-state arbitration, just as another World Bank initiative around the same time offered depoliticization through a different tool, political risk insurance. ${ }^{18}$ It is important to understand that ICSID arbitration was a response to the on-going disagreement about appropriate substantive binding international norms for arbitration; ICSID allowed the parties to the dispute freely to choose the legal norms to which they would agree as the applicable law of the arbitration, which would often be a contract between the investor and the host state. Bilateral investment treaties did already exist but they were characterized by state-to-state dispute settlement. Interestingly, it was a plurilateral/multilateral instrument, the OECD Convention on the Protection of Foreign Property (1967), which seemingly first contemplated investment arbitration for treaty violations. ${ }^{19}$ At the same time, during this period, the 1960 s and 1970 s, efforts to achieve agreement on substantive norms through multilateral initiatives failed, as Miles notes, "largely due to the differing viewpoints of capital-exporting and host states on the appropriate standards for investor protection." 20

The 1980s and 1990s were the watershed: the number of BITs increased dramatically, the great bulk of them including compensation for expropriation, FET and NT provisions, and ISDS. As is widely commented, this development was deeply linked to the end of communism and the rise of the Washington Consensus/neoliberal approach to economic development, where free trade and liberalization of investment flows are standard prescriptions. Entering into BITs was thought to increase foreign investment into developing countries by providing valuable protection against political risk to the investor. At the same time, there were initiatives led by developed countries to multilateralize norms of investor protection through the GATT/WTO; those efforts failed in the Uruguay Round, and then an OECD-centred process (the Multilateral Agreement on Investment), which also failed. ${ }^{21}$ In sum, while developing countries especially (but far from exclusively) were unwilling to agree on neoliberal-oriented norms of investor protection as global law, they acceded to these norms in BITs on the

18 See I. Shihata, Towards a Greater Depoliticization of Investment Disputes: The Roles of ICSID and MIGA (1993).

19 Thanks to Maxim Berdichevksy for pointing this out to me.

20 Miles, supra note $16,85$.

21 Ibid., 116-119. 
basis of the prevailing view that this was necessary not as a matter of what is required for a just or efficient global order, but rather to execute what had become normalized as the obvious development strategy of incentivizing foreign investment.

By the end of the 1990s, prominent economists such as Joseph Stiglitz and Dani Rodrik were questioning the neoliberal/Washington Consensus prescriptions for economic development. While these had appeared to work in some countries, the Asian Tigers, they were less successful elsewhere (and even in Asia, there was more use of protective industrial policies than initially had been conceded). The thinking in places like the World Bank shifted to problems with institutions in transitioning and developing countries; could the neoliberal prescriptions not be working in some countries because of weak governance and legal institutions? In this context, some of the provisions in BITs, combined with ISDS, could be considered as substitutes for robust domestic institutions of a kind needed to support economic growth driven by foreign investment and open trade. This mapped on to much older views about the importance of property rights and rule of law generally to economic development.

Around the beginning of the $21^{\text {st }}$ century, the number of claims and awards under BIT-based ISDS multiplied. Many of the disputes looked different from the classic cases of a dictatorship nationalizing a mine, for example, or abusive police powers being used to push out a foreign investor who has become unpopular with local elites. Some claims asked host states to pay for governance mistakes including botched privatizations in early stages of transitions from communism or other command-and-controltype economic approaches. But it was probably the arbitrations over Argentina's measures to address a fundamental economic crisis that drew international attention to the implications of BIT-based ISDS for regulatory autonomy, and the risk that legitimate public policies could be frustrated by investor protection. Some of the arbitral awards found that Argentina's actions could be justified on the basis of necessity or public policy exceptions in treaties. This led naturally to considerable debate as to whether, since other awards went the other way, ISDS could be used or abused to thwart legitimate important policies. Awards against Canada, a developed country, provoked further scepticism, as increasingly ISDS was being justified as a substitute rule of law for countries with weak governance and legal institutions. Almost simultaneously a body of empirical scholarship was emerging that tested whether BITs actually lead to increased flows of FDI. No consistent pattern can be detected across the many different studies using varying methodologies, except that few of them suggest a major 
impact in terms of increased FDI; moreover, all of the studies are vulnerable to serious methodological criticisms. While monetary awards against host states, combined with anecdotal evidence of regulatory chill, have provided considerable information about the costs to host states in offering treaty protection to foreign investors, the evidence as to whether there is a benefit from doing so in terms of increased FDI is both highly ambiguous and highly unreliable. It is against this broad-brush historical sketch that the current controversies over investor protection and ISDS particularly should be understood.

Most justifications for the investment regime invoke one or more of the following rationales, which reflect the different functions that the regime has been seen to play in different time periods discussed above: 1) treaty protection provides an incentive to foreign investors that results in an increase in the kind of FDI that has positive impacts on the countries concerned, including positive developmental impacts in the case of poor countries; 2) treaty protection can function as an incentive for countries to improve governance and the rule of law to meet international standards, or as a substitute for domestic rule of law where it is weak or based on a political or economic system unacceptable to investors and the countries they come from; 3 ) international justice (fairness in the treatment of aliens); 4) treaty protection disciplines inefficient discriminatory barriers to FDI just as WTO norms do in the case of trade, thereby allowing a continuity of legal disciplines on protectionism across external contracting (trade) and internal contracting (investment) of the firm.

\section{Rationales for Investor Protection in International Law}

\section{A. Investment treaty commitments as an investment incentive}

As a general matter, economists are sceptical of the case for compensating economic actors for regulatory change. Notably, one of the only sustained treatments of treaty-based investor protection by a leading economist is Joseph Stiglitz's critique of the compensation of foreign investors for regulatory change by the host state. ${ }^{22}$ Stiglitz observes that in at least some arbitration awards, the fair and equitable treatment provisions, as well as the

22 J.E. Stiglitz, Regulating Multinational Corporations: Towards Principles of Crossborder Legal Frameworks in a Globalized World: Balancing Rights with Responsibilities, 23 American University International Law Review (2008), 451. 
meaning of compensable expropriation, have been interpreted as protecting investors against regulatory change-through a broad interpretation of the meaning of "expropriation" to include all regulatory changes that have the economic impact of a direct taking and also through understanding fair and equitable treatment as protecting investors' "legitimate expectations" with regard to the regulatory framework. There is no generally valid economic case for compensating private actors for regulatory change, as law and economics scholars such as Louis Kaplow ${ }^{23}$ and Richard Revesz ${ }^{24}$ have pointed out. Why then does it make sense that foreign investors enjoy such protections under international law? As Stiglitz indicates, there might be situations where economic actors are not able efficiently to self-insure against costs of regulatory change, but one would expect political risk insurance markets to fill this gap. In our research on the largest political risk insurance provider for foreign investors, the World Bank Multilateral Investment Guarantee Agency (MIGA), Efi Chalamish and I come to the tentative conclusion that there is no reason in principle to think that there are gaps in political risk insurance markets that would necessarily need to be filled by general treaty protections. ${ }^{25}$

Rather than focusing on market failures in the political risk insurance market that lead to sub-optimal allocation of the general risk of regulatory change, such limited economic literature that exists tends to focus on one particular situation where it is intuitively plausible, due to moral hazard, that the risk is not well-managed by political risk insurance; this is the hold-up scenario where, opportunistically, the host state extracts rents from an investor who is trapped, as it were, with project-specific and largely immobile assets in the host state, either through expropriation or other rent-

23 L. Kaplow, An Economic Analysis of Legal Transitions, 99 Harvard Law Review (1986), 509. Kaplow shows that firms can manage the risk of regulatory change through a variety of market mechanisms - there is no convincing case of market failure that suggests the need for the government to intervene.

24 J.R. Nash \& R. Revesz, Grandfathering and Environmental Regulation: The Law and Economics of New Source Review, 94 New York University Law and Economics Working Papers (2007), 47 ("Rules of legal transition relief are inadvisable because they give rise to poor incentives: They discourage actors from anticipating changes in legal rules, and they encourage actors to seek economic rents from transition relief regimes.").

25 E. Chalamish \& R. Howse, Conceptualizing Political Risk Insurance: Toward a Legal and Economic Analysis of the Multilateral Investment Guarantee Agency (MIGA), in E. Chalamish \& R. Howse, The Transnational Law of Public Contracts (2015). 
shifting regulatory changes. The hold-up rationale for treaty protection of investors is well-articulated by Bown and Horn:

At a superficial level, the expropriation problem is simple: a potential source country government and a potential investor jointly benefit from an investment. But since the investment is irreversible, it will be at the mercy of the host country government once it is made. Realizing that the government will have incentives to extract the surplus that the investment will generate once it is in place, the subgame perfect equilibrium strategy for a rational potential investor is to abstain from investing. The surplus that the investment could create is thus never realized, to the detriment of both parties. There is hence scope for some form of contractual arrangement that makes the expropriation costly to the host country-a state-to-state investment agreement could be one such arrangement. We denote this as the hold-up model of international investment agreements in recognition of the fact that the depicted situation is a special case of a hold-up problem. [footnote omitted]. While investment agreements are normally depicted as preventing expropriations in the theoretical literature, they could in principle (and practice) also take less drastic forms, such as changes in regulations ex post the investment that deprive investors of profits, and that benefit host countries. ${ }^{26}$

Kohler and Stahler note:

Almost all investment implies exposure to political risk: Once upfront cost is sunk the sovereign may change the legal environment, say through regulatory standards, such that the ex ante incentives for the investment is put into question ex post....in many cases enforceable contracts between the government and the host state cannot be written. At the same time, the investment is often relationship-specific, such that it has little (if any) value outside the host country. Due to anticipation by foreign investors, regulatory risk may thus lead to beneficial investments not being carried out at all, or not carried out to the socially optimal amount. ${ }^{27}$

According to Kohler and Stahler, investment treaties with ISDS "are intended to indemnify foreign investors if host country government policies

26 Bown \& Horn, supra note 10, 29-30.

27 W. Kohler \& F. Stahler, The Economics of Investor Protection: ISDS versus National Treatment, CESifo Working Paper Series (2016), 1. 
are causing 'unjustified' harm through an ex post erosion of investment incentives." As Aisbett, Karp, and McAusland clarify, solving the hold-up problem through treaty-based investor protection may make sense, where the ex post erosion of investment incentives is caused by inefficient regulation; in order to extract ex post from the firm that has a trapped investment, the government adopts a sub-optimal regulatory instrument. ${ }^{28}$

As Bown and Horn indicate, there is a range of assumptions that have to hold true in order for the hold-up model of IIAs to work. I see three particular premises that require careful examination, and probably to evaluate them adequately requires considerable new research: 1) additional FDI is likely to promote economic growth and development, especially in developing and transitional economies; 2) treaty-based investment protection will induce additional amounts of such FDI than under a scenario where investors and states are limited to contractual or other non-treaty devices for managing the hold-up problem; 3) treaty-based investment protection is cost-effective; the downside risk is worth it, particularly when compared with other strategies for incentivizing investment.

\section{Premise I: Additional FDI will boost economic growth and development}

An active debate exists in the economic policy literature about whether increased foreign investment is a desirable development strategy or whether building efficient domestic capital markets and/or public investment strategies should instead be the emphasis. ${ }^{29}$ The most sophisticated treat-

28 E. Aisbett et al., Compensation for Indirect Expropriation in International Investment Agreements: Implications of National Treatment and Rights to Invest, 1(2) Journal of Globalization and Development (2010), 1, 1-33.

29 Thomas Piketty suggests that none of the countries that have seen rapid growth and development in Asia received massive FDI, instead largely self-financing the needed infrastructure and improvements in human capital. T. Piketty, Le capital au XX siècle (2013), 120-121. See also JJ. Laffont, Regulation and Development (2005); JJ. Laffont \& J. Tirole, Privatization and Incentives, 7 Journal of Law, Economics and Organization (1991), 84. By contrast, for a model of how FDI can lead to growth and economic development, see M. Bengoa \& B. Sanchez-Robles, Foreign Direct Investment as a Source of Endogenous Growth, 5 Universidad de Cantabria, Economics Working Papers (2003), 1. Bengoa and Sanchez-Robles argue: "In particular, FDI brings about growth because it facilitates the entry of intermediate goods of more advanced technology in the host country, thus increasing both domestic capital and output... 
ments of this question note that "the main lesson might be that the search for universal relationships (between FDI and development) is futile"30 while stressing the importance of, inter alia, the quality of domestic governance and institutions, infrastructure, and human capital to the ability of FDI to contribute positively to development. ${ }^{31}$

At the same time, not all FDI is alike. For example, in some contexts FDI in natural resources may exacerbate the "resource curse" pathology and create unmanageable negative environmental externalities. Moran finds that " $t]$ he difference between negative outcomes and positive outcomes from FDI in natural resources centres on the well-established need for transparency in revenue streams, for controls to prevent corruption, and for measures to set and enforce best-practice environmental standards." 32

Thus, if incentivizing additional FDI through treaty-based investor protections is to be justified as a sound policy for economic development, we would need to know: 1) whether the kinds of countries where this incentive is likely to be effective are the same kinds well-positioned to gain developmental benefits from FDI, and 2) whether the kind of additional FDI likely to be generated due to this kind of incentive is positive or negative (or indifferent) for development. Sachs and Sauvant point out with respect to those studies that suggested a positive correlation between treaty protection and increased FDI flows that "BITs may be relatively more influential in certain countries or contexts than in others, depending on the type of investments common to a country or the mix of other-more crucial-FDI determinants. The magnitude of the correlation between BITs and FDI, then, may vary for various countries and regions for reasons that are not captured or explored in the studies." 33 There is a serious gap in the literature, in other words, and thus from a policy perspective, one is forced, for now, to rely on speculative hypotheses and anecdotal evidence.

30 T. Moran et al. (eds.), Does Foreign Direct Investment Promote Development? (2005), 5.

31 C. Jude \& G. Levieuge, Growth Effect of FDI in Developing Economies: The Role of Institutional Quality, 559 Banque de France Working Papers (2015), available at https://papers.ssrn.com/sol3/papers.cfm?abstract_id=2620698 (last visited 6 December 2018).

32 T. Moran, 'Is FDI in Natural Resources a Curse?' (2010), available at https://www. wto.org/english/res_e/publications_e/wtr10_forum_e/wtr10_moran_e.htm (last visited 6 December 2018).

33 L. Sachs \& K. Sauvant, BITs, DTTs, and FDI flows: An Overview, in L. Sachs \& K. Sauvant, The Effect of Treaties on Foreign Direct Investment: Bilateral Investment Treaties, Double Taxation Treaties and Investment Flows (2009). 
One could surmise that one indication an investor is likely to value treaty protection with respect to a particular country or kind of investment and thus possibly be incentivized by it to invest is historically against what kinds of countries and with respect to what kinds of investment investors have found it useful to bring treaty-based claims in investor-state arbitration. UNCTAD's investment dispute settlement database records 811 claims against 131 countries. While the largest number of claims against a single host state is against Argentina (in the context of its financial crisis), arguable "resource curse" states account, individually, for significant numbers of claims: Kazakhstan, 31; Kyrgyzstan, 13; Russian Federation, 24; Venezuela, 41; Uzbekistan, 7; Turkmenistan, 9; Moldova, 10. When we turn to the kind of investment, extractive industries and service supply dominate overwhelmingly with 688 claims while manufacturing generated a mere 115 claims. ${ }^{34}$ Thus where according to the literature FDI seems most associated with developmental gains, investors seems least likely to find they need to use treaty protection. On the other hand, the protection of these treaties is invoked frequently by investors in sectors and against countries where FDI may well be, in many cases, associated with negative developmental effects or governance pathologies.

While FDI may not have positive effects or may even have negative effects in the host state in "resource curse"-type situations, it is completely understandable why these would precisely be the kinds of situations where investors would gain the most from protection; in extractive industries, the costs are more front-loaded than in manufacturing (generally speaking) in that a larger fraction of the costs take the form of irreversible or trapped investment costs in project-specific assets. This is why there are more rents in these industries. And these rents invite rent-seeking, especially where, as in the case of resource curse countries, there are few constitutional, legal, or institutional constraints on government actions to extract rents.

This is entirely consistent with a different possible indication of what countries and sectors for which investors may find protection against regulatory change valuable enough to make an investment that would otherwise not happen: namely, the willingness of investors to allocate scarce resources to protections against regulatory change through contractual bargaining of clauses that stabilize, in whole or in part, the regulatory environment. The most comprehensive study to date of stabilization clauses found

34 UNCTAD Investment Dispute Settlement Navigator (2017), available at http://inv estmentpolicyhub.unctad.org/ISDS/FilterByApplicableIia (Last visited 6 December 2018). 
that close to $78 \%$ of those clauses that fully or partially freeze the regulatory framework (or have some characteristics of such freezing) pertain to extractive industries and energy; a similar percentage of the clauses was accounted for by regions where there is a significance of "resource curse" countries, as well as, more generally, countries with governance and institutional weaknesses that make it less likely that they can take advantage of FDI for domestic economic development. ${ }^{35}$

These impressionistic observations are, of course, not a substitute for a rigorous analysis of the data. But they generate a working hypothesis: investors whose activities generate significant negative externalities (environmental, health, etc.) will be the most attracted to treaty protection when they are investing in countries with low regulatory standards and weak governance-precisely where FDI is apt to contribute least to positive economic development. Where there are low regulatory standards, the investor faces a risk that these will be raised where high negative externalities from the investment become apparent, perhaps creating local political unrest; weak governance means that the legal and regulatory environment may shift dramatically depending on the fate of personal relationships with high officials, e.g., which members of the ruling family or clique are influential and which are on the outs at a given moment; on the other hand, where the investment is important to domestic economic activities and/or is generating public goods, a treaty is less needed because the host already faces a significant domestic downside in enacting regulatory changes that make operating in that country difficult or unattractive for the investor. ${ }^{36}$

35 A. Shemberg, 'Stabilization Clauses and Human Rights A Research Project conducted for IFC and the United Nations Special Representative of the SecretaryGeneral on Business and Human Rights Tables 6.1 and 6.2' (2008), available at http://documents.worldbank.org/curated/en/502401468157193496/Stabilization-cl auses-and-human-rights (last visited 6 December 2018).

36 L. Johns \& R. Wellhausen, Under One Roof: Supply Chains and the Protection of Foreign Investment, 110 American Political Science Review (2016), 1, 31, "host states are significantly less likely to take actions that negative affect the property rights of foreign investors where the investment is positively linked to domestic economic activity. Chalamish and Howse surmise that one reason that MIGA has rarely had to pay out claims under its political risk insurance is that MIGA prescreens projects through, inter alia social and environmental assessment; where investments generate positive externalities to the domestic economy (certainly, as opposed to generating negative ones), host states have stronger incentives to settle disputes with the investor in a manner that allows the project to continue on good terms.. 
In sum, even if it turns out to be true that some additional FDI is incentivized by investment protection, this might not be the kind of FDI that is beneficial to economic development, or it might not be directed towards the kinds of countries likely to benefit developmentally from FDI (e.g., disproportionately "resource curse" states). Ultimately, the current state of economic research doesn't allow us to say. However, as will be discussed below, even and especially in these particular cases, it may well be that it is contractual protection (or third-party political risk insurance) not the existence of a BIT that is decisive for the investment decision.

At the same time, it may be argued that, whatever the first-best developmental strategy for poor underdeveloped countries, they will often face an immediate situation where their resources, particularly natural resources, will simply not get put to productive economic use without FDI. In fragile or failed states, crucial infrastructure and public services may require the presence of foreign investors, who given the political instability, governance deficits, and perceived high risk of the "hold-up" scenario in such circumstances, are unlikely to participate without the kind of protection offered by a treaty. This is, of course, plausible. Although the question would be whether participation and risk sharing by development banks or political risk insurance offered by the World Bank through MIGA would be preferable solutions to the dilemma in question, as they do not create the kind of open-ended future liability that treaty protections do. This issue will be explored in the discussion below of Premise III.

\section{Premise II: Treaty Protection is Likely to Incentivize Additional FDI}

A useful starting point for theorizing the relationship between treaty protection and FDI flows is to ask: does the allocation or reallocation of political risk through market mechanisms such as investment contracts with stabilization clauses and political risk insurance generate a sub-optimal level of FDI? If so, what market failure or failures explain this? The (albeit meagre) scholarly literature that addresses the question takes a sceptical view of the notion that market mechanisms are sub-optimal. ${ }^{37}$ (On the other hand, the possibility that BITs actually impede efficiency in contractual bargain-

37 Stiglitz, supra note 22; S. Halabi, Efficient Contracting Between Foreign Investors and Host States: Evidence from Stabilization Clauses, 31 Northwestern Journal of International Law and Business (2011), 261. 
ing by allowing investors to engage in certain types of opportunistic behaviour under the contract should not be dismissed; this will be discussed below.)

One reason that contractual bargaining between states and firms might not always be the best means of allocating political risk in order to optimize FDI flows is that there are significant agency costs entailed in such bargaining. Self-interested state bargaining agents may, in return for bribes or other rents from investors, agree to stabilization clauses that are not in the public interest. This risk is exacerbated by the fact that stabilization clauses are very often contained in secret agreements between firms and state bargaining agents. But this would less demonstrate the logic of treaty protection over contractual mechanisms as the advantages of political risk insurance by third parties.

To my knowledge, none of the literature advocating BITs as an instrument of incentivizing additional FDI flows has plausibly identified systematic failures in the political risk insurance market. Of course investors pay a premium for political risk insurance. But we would then have to ask why it would benefit a host state seeking to incentivize the investment to offer treaty protection coverage to all potential investors, regardless of the extent to which the particular investment is likely to be a net positive social value to the economy and regardless of investment-specific levels of political risk. Instead the state could partly or fully subsidize the cost of particular investors obtaining political risk insurance from a third party in those cases where the specific investment is deemed socially desirable, and where it is plausible that the investment will not occur but for the subsidy. (One answer could be that a state's officials are ill-equipped to know where FDI is likely to provide positive versus no or negative social value; if this is the case, a key challenge is to put in place policy frameworks and expert resources that allow such judgments to be made; one benefit of political risk insurance by MIGA, for instance, is that ex ante assessments of this kind are required in order to insure a project; UNCTAD does extensive work with developing country governments to assist those countries in putting in place policy frameworks for investment.)

Even if one were to assume that political risk insurance is unsuited, given information asymmetries and moral hazard problems, to solving the hold-up problem, it is much less clear why contractual arrangements between particular investors and the host state cannot do so; such contracts can be enforced in a similar way to treaty protections (ICSID and the New York Convention) and they do often, through stabilization and related provisions, seem to directly address the hold-up scenario. 
Van Aaken offers to my mind the most plausible hypothesis as to why treaty protection offers to improve the outcome over contractual solutions. ${ }^{38}$ Drawing on the theory of incomplete contracts, van Aaken notes the challenge of defining ex ante through contractual bargaining the specific kinds of regulatory changes that constitute a hold-up of the investor. There is a very wide range of policy interventions through which a host state might attempt to extract rents from an investor; there would be very high transaction costs, arguably, to specifying these exhaustively in a contract between the investor and the host state. The host state might, for good reason, given uncertainty about the future, not want to lock itself in to contractual provisions that freeze the existing regulatory framework. The investor will be concerned with the risk of being held up through some kind of regulatory change not explicitly covered in the contract. Given the flexible or broad notions of indirect expropriation (at the limit, any regulatory act that takes significant economic value from the investor) and FET, treaty protections for investors could then be seen as a solution to the incomplete contract problem: contractual arrangements cannot be structured to address adequately opportunism concerns ${ }^{39}$ (at least at an acceptable level of transaction costs). This would be so, if the legal standards and dispute settlement procedures of IIAs could be designed such that the adjudicator accurately completes the contract ex post; i.e., she properly determines whether, under conditions of perfect information and zero transaction costs, the regulatory event in question is the kind of event that the parties would have agreed to be compensable or otherwise constrain, i.e., in a complete contract.

The question, though, is whether given all the devices investors and host states might use to address the incomplete contracts problem, treaty protection is sufficiently valuable to investors that it can incentivize socially desirable investment that would otherwise not occur. The investor and indirectly also the government (if investment is increased) might benefit from an IIA that lays down in general terms some constraints on future policies. But when designing this IIA, the contracting governments face the same type of informational problems as when they negotiate long-term investment contracts with individual investors. Indeed, these problems are compounded in the case of IIAs in that they will apply across a broad

38 A. van Aaken, International Investment Law Between Commitment and Flexibility: A Contract Theory Analysis, 12 Journal of International Economic Law (2009), 507.

39 See discussion below of the hold-up problem. 
range of industries. Firm-, sector-, and project specific risk are unpriced. On the other hand, it is possible to include in investment contracts in addition to specific stabilization commitments, the same general legal standards as in IIAs such as protection against expropriation and the obligation of fair and equitable treatment. Indeed, to the extent that there is public knowledge of the content of these contracts (which are very often secret), it seems that they may well contain general standards similar or identical to those in BITs in addition to specific stabilization commitments. Just as with IIAs, then, the general legal standards in question delegate to the adjudicator the completion of the contract.

It could be, however, that there is a significant range of situations where general protections such as those in IIAs would sufficiently allay investors' concerns about the hold out problem without requiring the negotiation of specific stabilization commitments in an investment contract. If this were so, then the host state could achieve the objective of having the investment be made without the transaction costs of negotiating a contract. On the other hand, it may be that where investors are concerned about the holdup problem to the extent that it affects the decision as to whether to invest or not, in those cases investors will typically require investment contracts. There is some evidence to this effect, in fact, as will be discussed below; in the case of extractive industries, where the hold-up scenario matters a lot to investors, they typically seek to negotiate investment contracts with the host state.

As is now fairly well recognized, the empirical evidence about the effects of IIAs on investment flows is deeply contradictory: many of the most sophisticated studies point to little if any positive effect on foreign investment inflows as a consequence of entering into a bilateral investment treaty. Bellak, analyzing those studies that were available up to 2015 , and taking into account methodological differences, concludes: "In a nutshell, the positive impact of BITs on FDI has not been confirmed empirically". 40 A possible exception is of transitional economies, where the treaty protec-

40 C. Bellak, Economic Impact of Investment Agreements, 200 Vienna University of Economics and Business, Department of Economics Working Papers (2015). See for example M. Hallward-Driemeier, Do Bilateral Investment Treaties Attract FDI? Only a Bit and They Could Bite, 3121 World Bank Policy Research Paper (2003), finding no strong correlation between entering into a BIT and increased flows of inward FDI (but not taking into account possible signalling effects); similarly J. Tobin \& S. Rose-Ackerman, Foreign Direct Investment and the Business Environment in Developing Countries: The Impact of Bilateral Investment Treaties, 293 Yale Law School, Center for Law, Economics and Public Policy Research Paper 
tions may be one signal among others to investors that domestic policy is shifting from one hostile to foreign investment to an overall favourable attitude. ${ }^{41}$ In evaluating the emerging climate for investment in a shifting transitional environment, foreign firms may face particularly high information costs in evaluating the seriousness, depth, and durability of reforms that positively affect the climate for investment. Thus, it is understandable that in this one kind of situation foreign investors might rely for their investment decisions to a greater extent than otherwise on the signals sent by treaty commitments. On the other hand, it is precisely in transitional situations where the costs of pre-commitment may be highest, given the need for regulatory experimentalism ${ }^{42}$ and the importance of allowing an emerging constitutional democracy to reconsider interim or transitional regulatory choices.

(2005) and E. Aisbett, Bilateral Investment Treaties and Foreign Direct Investment: Correlation versus Causation, 225 Munich Personal RePEc Archive Paper (2007) (coming to similar conclusions). For contrary results, see E. Neumeyer \& L. Spess, Do Bilateral Investment Treaties Increase Foreign Direct Investment to Developing Countries?, 33 World Development (2005), 1567 and J. Salacuse \& N. Sullivan, Do BITs Really Work? An Evaluation of Bilateral Investment Treaties and Their Grand Bargain, 46 Harvard International Law Journal (2005), 67. There are many problems with trying to measure the impact of the commitments in bilateral investment treaties on investor behaviour through correlating the entry into the treaties with changes in the aggregate flow of FDI. Some of these are discussed in an illuminating fashion by Aisbett (especially the problem of endogeneity). Arjan Lejour and Maria Salf point out that one common feature of the studies that find a strong positive correlation between treaty protection and FDI flows is that these studies fail to address the possibility of reverse causality: "On the one hand, signing or ratifying a BIT can attract larger amount of investment, on the other hand, a high level of investment in a country can also be an incentive to sign a treaty." A. Lejour \& M. Salf, The Regional Impact of Bilateral Investment Treaties on Foreign Direct Investment, 298 Netherlands Bureau for Economic Policy Research, CPB Discussion Paper (2009). For studies finding a positive impact of BITs on investment flows, see e.g. A. Kerner, Why Should I Believe You? The Costs and Consequences of Bilateral Investment Treaties, 53 International Studies Quarterly (2009), 73.

41 See A. Berger et al, 'More Stringent BITs, Less Ambiguous Effects on FDI? Not a Bit!', available at https://pdfs.semanticscholar.org/654b/2649cc511906cdb1b14f392 50efba21e037f.pdf (last visited 6 December 2018).

42 See generally D. Rodrik, One Economics Many Recipes: Globalization, Institutions and Economic Growth (2009). 
Premise III: Treaty Protection is a Cost-Effective Investment Incentive Relative to Other Kinds of Incentives a Host State Might Provide

This brings us to the third premise: that treaty protection can function as an investment incentive, even assuming this could be established, would not necessarily justify host states agreeing to it. At least given the design of many if not most existing IIAs, both substantive protections and dispute settlement provisions, there is a significant downside risk that IIAs will deter, or make more costly, regulatory changes that are socially desirable (rather than simply disciplining opportunistic inefficient rent-extracting moves by host states). A wide variety of incentives can be used to attract FDI, ${ }^{43}$ including subsidies, favourable tax treatment, improvements in infrastructure, and human capital. Brazil is an example of a developing country that has attracted significant FDI while not providing any IIA protection to investors; but Brazil offers other incentives (for instance, tax relief where foreign investors train or re-train workers). ${ }^{44}$ The quality and quantity of other incentives might make it acceptable for investors to invest regardless of the hold-up problem.

There is little evidence that states attempted to analyze the relative costs and benefits of different investment incentives and how they might complement each other, prior to entering into investment treaties. To the contrary, in his landmark study Bounded Rationality and Economic Diplomacy, ${ }^{45}$ Lauge Poulsen has shown that in most cases developing countries responded to demands for BITs without detailed information or analysis of the implications of the obligations or the costs and benefits. Given the limits of their knowledge and resources, officials simply didn't question the underlying logic of entering into agreements when these deals were proposed to them. The presumption that a BIT was a "normal" agreement was clearly

43 See T. Harding \& B.S. Javorcik, Roll Out The Red Carpet and They Will Come: Investment Promotion and FDI Inflows, 121 The Economic Journal (2011), 1445. See also A.T. Tavares-Lehmann et al. (eds), Rethinking Investment Incentives: Trends and Policy Options (2016).

44 KPMG International, 'Nearshore Attraction: Latin America Beckons as a Global Outsourcing Destination', (2009), available at https://www.kpmg.de/docs/Nearsho re_Attraction_Latin_America_as_Outsourcing_location_2009.pdf (last visited 6 December 2018).

45 L. Poulsen, Bounded Rationality and Economic Diplomacy: The Politics of Investment Treaties in Developing Countries (2015); see especially L. Poulsen, Bounded Rationality and the Spread of Investment Treaties, in L. Poulsen, Bounded Rationality and Economic Diplomacy: The Politics of Investment Treaties in Developing Countries (2005). 
enhanced by the practice of using boilerplate or model agreements to propose the terms of such treaties to a large number of countries.

Treaty protection has features that distinguish it from other forms of investment incentive, and these may well affect any judgment concerning its relative cost-effectiveness. First of all it is not targeted. It is available to all foreign firms that can create a corporate structure that allows them to claim as a national of a state that is bound by the treaty (often a matter of paper reorganization of affiliates), regardless of what kind of benefits those firms may provide to the local economy-or what social costs (negative externalities) may accompany their activity in the host state. The relevant policy literature tends to view targeted incentives as more powerful than untargeted ones: "Investment promotion practitioners believe that the most effective way of attracting FDI is to focus on a few priority sectors (so called targeting) rather than attempt to attract all types of foreign investors." ${ }^{46}$ Again, where a government does not have the capacity to engage in effective bargaining, one might think a treaty is the better answer; if investors not states have superior information about the positive synergies between a potential investment and the host state's economy, i.e., offer such protection to all potential investors and see who shows up.

On the other hand, failure to target properly investment incentives can leave governments facing very significant costs, with little or no benefit to show. As noted above, a very large percentage of pay-outs to investors under investment treaties occur in extractive industries. At the same time, a study by Elkins, Guzman, and Simmons suggests investors have generally relied on investment contracts to manage political risk with respect to investments in extractive industries, bargaining for specific commitments from the host state. Investor protection is particularly important to investment decisions in extractive industries, but the kind of protection that is apt to influence the decision to invest is contractual. ${ }^{47}$ There may be a limited value, however, in this study because it lacks explicit treatment of many other potential explanatory variables.

46 Harding and Javorcik, supra note 43, 5. See also for example P. Egan, Crawling Up the Value Chain: Domestic Institutions and Non-traditional Foreign Direct Investment in Brazil, 1990-2010, 35 Revista de Economia Politica (2015), 156; N. Kumar, Globalization and the Quality of Foreign Direct Investment (2002); R. Nelson, Harnessing Globalization: The Promotion of Nontraditional Foreign Direct Investment in Latin America (2009).

47 Z. Elkins et al., Competing for Capital: The Diffusion of Bilateral Investment Treaties, 1960-2000, 60(4) International Organization (2006), 811, 843. 
One feature of treaty protection as an investment incentive is that the political benefits are often front-loaded while the cost, in terms of either compensation to investors for regulatory change or constraints on otherwise optimal regulatory change, is born in the future by some government, often not the same one that has entered into the treaty commitment. In the case of subsidies, tax breaks, and other targeted export promotion measures, the cost to the state is explicit (or at least measurable) and is only partly in the nature of a future liability; in democracies, these kinds of measures are likely to engage some level of political awareness and discussion, would often have to be voted by legislatures, and might well be timelimited. Pre-commitment through treaty protection for investors is an illustration, one might say, of Jon Elster's general insight that governmental hands-tying is usually a way of binding others. ${ }^{48}$

Political economy considerations might well explain why some governments would, all things being equal, choose an investment incentive like treaty protection where the cost of the incentive (a payoff under the treaty) is likely to be deferred until the government is out of power, and hard for critics or sceptics to estimate or quantify at the time at which the decision is made to enter into a treaty (this was especially the case before states had the experience of suffering multi-million or even billion dollar awards under the treaties). In some cases, a regime committed to a neoliberal ideology may wish to make it more costly for a subsequent government, say of a more social democratic stripe, to reverse its free-market reform agenda. Wickelgren models the effect of governments being able to make longterm commitments that bind their successors, showing how government pre-commitments to private economic actors "allow an incumbent government...to inhibit the effectiveness of elections in aligning policies with social welfare." ${ }^{49}$ While Wickelgren's conclusion is that in the case of government contracts damages should be reduced below expectation levels (the latter being the current norm in the case of breaches of investment treaties), leading law and economics scholar Eric Posner makes the case that there should not be any judiciable government contracts resulting in damages. This sort of hands-tying "creates a perverse incentive for govern-

48 J. Elster, Ulysses Unbound (2000).

49 A. Wickelgren, Damages for Breach of Contract: Should the Government Get Special Treatment? 17 Journal of Law, Economics and Organization (2001), 121, 125. See also J. Tirole, The Internal Organization of Government, 46 Oxford Economics Papers (1994), 1. 
ments to externalize costs on later governments." ${ }^{50}$ While the analyses of Wicklegren and Posner assume that the government pre-commitment is in the form of a contract, the problems they identify with enforceable precommitments resulting in damages awards apply even more strongly to treaty protection for investors, which is much more open-ended and (subject to any specific exceptions or reservations in the treaty) could be deployed to make changes in almost any area of public policy costly for the new government. Seeking to make one's legacy as irreversible as possible is a well-observed form of political behaviour. ${ }^{51}$ The tension between electoral democracy and long-term hands-tying by incumbent governments may be reflected in the fact that a state that is a democracy, and especially one that is becoming more democratic, has a significantly greater likelihood of terminating its BITs. ${ }^{52}$

In sum, treaty protection of foreign investors may have political benefits where the current government that pre-commits the state and ties the hands of its successor, even if they are less effective than certain other (targeted) investment incentives. But these very political benefits come at a cost to democratic values and processes. If treaty protection, however, is limited to restraining rent-extracting "hold-up" tactics by the host government, and dispute settlement allows robust and consistent distinctions between such hold-ups (compensable) and other kinds of regulatory changes that reflect alteration in political preferences, or new information about environmental risks for example (non-compensable), then one can argue that there is a benefit in terms of optimal public policy, not a "cost"-what are likely "inefficient" rent-shifting policies are the ones that are disciplined. On the other hand, regulatory chill is avoided, since governments can be confident that the adjudicative system yields predictable, consistent outcomes, where hold-up scenarios are distinguished from other kinds of regulatory changes. This will become a key issue when in the next parts of the paper we turn to the fit or misfit between existing treaty designs and dispute settlement designs and rationales for treaty protection of investors.

For now it is important to recognize that solving the hold-up problem through investor protection creates moral hazard on the investor side.

50 E. Posner, Courts Should Not Enforce Government Contracts, 132 University of Chicago Law and Economics, Olin Working Papers (2001), available at http://dx.d oi.org/10.2139/ssrn.281436 (last visited 6 December 2018).

51 H. Gersbach, Statesmen, Populists and the Paradox of Competence, 301 University of Heidelberg Discussion Papers (1999).

52 J. Alqueres, On the Termination Value of Bilateral Investment Treaties: Trading Sovereignty for FDI, New York University Working Papers (2016). 
Where there is treaty-based investor protection with ISDS, an investor may feel freer to engage in activities that are harmful to the environment or other social interests, knowing that if the government responds by stricter regulation the investor has recourse to compensation, or can even forestall such stricter regulation or mitigate through the threat of an ISDS claim. When an investor seeks an investment incentive, say a license or concession on favourable terms, or monopoly rights (privatization of a utility for example), it may understate the risks or social costs posed by the investment or overstate the likely social benefits. This is possible due to information asymmetries: the firm controls a great deal of information that may relate to the social costs and benefits of the investment, and will often not have an interest in sharing this information ex ante. In the absence of treaty protection, the investor must face uncompensated risks that the government will take a range of corrective actions when it discovers post that the social costs and benefits of the investment are different than as they appeared to the government ex ante; these could include re-regulation, loss of licenses and concessions, and even reversal of privatization of essential services such as provision of water or electrical power. Where these risks are reduced through investor protection that triggers compensation to the investor when these corrective actions are taken, moral hazard may be greater. The question in part is whether substantive norms of investor protection as well as the dispute settlement system can take into account opportunism on the part of the investor where there is material non-disclosure or even misrepresentation ex ante of the social costs and benefits of the investment. Here, attention needs to be given to the relative difficulty of counterclaims under investment treaties, which only exceptionally provide for the possibilities that a state may make a counterclaim against an investor for misconduct, such as failure to comply with local laws or misrepresentation of its capacity to successfully complete the project. By contrast with treaty protection, investment contracts are inherently reciprocal and commitments by the investor may be as binding and subject to arbitration as those of the host state. (Because the ICSID regime was initially designed not with treaties but with contracts primarily in mind, it does allow for counterclaims.) In the case of political risk insurance, various pre-screening and monitoring devices may be used to control moral hazard on the investor as well as the host state side, as Chalamish and Howse explain. ${ }^{53}$

The case for treaty protection as an investment incentive faces very serious challenges in a number of respects. But perhaps most compelling is

53 Chalamish \& Howse, supra note 25. 
the lack of any clear trend of empirical evidence, after multiple studies with various methodologies, that making these kinds of commitments to investors actually produces any gains to the states who make the commitments, i.e., increased investment flows or more investments that are welfare-enhancing in the countries concerned. Nor has there been any significant challenge in the economic literature to Stiglitz's claim that compensating investors for regulatory change is generally not efficient and that political risk insurance or investor self-insurance is a presumptively better vehicle for managing risks to investors of regulatory change. Nor has the literature provided any clear picture of the choice of contractual protection against the hold-up scenario versus, or in addition to, treaty protection. This has not, however, stopped counsel and arbitrators from framing the issues in investor-state arbitration as if the essential function of the arbitrator was to complete ex post as it were an incomplete contract between the investor and the host state. Thus the repeated framing of disputes about fair and equitable treatment in terms of "legitimate expectations" of the investor with respect to the stability of the regulatory framework, and the tendency of tribunals to focus on breaches of promises or representations to the investor, even though it is in fact applying treaty law not enforcing an actual investment contract. ${ }^{54}$

Super-arbitrators such as Charles Brower use various kinds of rhetorical devices in the face of the lack of credible empirical evidence that investment treaties have little influence on inflows of FDI, including survey evidence that managers of firms say that such treaties matter to their investment decisions. ${ }^{55}$ As Poulsen indicates, most such surveys point in the other direction, suggesting few managers would see an investment decision hanging on the existence or absence of treaty protection (Poulsen takes into account here the one survey cited by Brower). ${ }^{56}$ Further, while business lobbies may publicly assert the importance of treaty protection to investment decisions, such statements should be treated like other instances

54 See J. E. Alvarez, Is Investor-State Arbitration Public?, 6 Institute for International Law and Justice - New York University Law School - Working Papers (2016), 9, 10. See also J. Arato, The Logic of Contract in the World of Investment Treaties, 58 William and Mary Law Review (2016), 351.

55 C. Brower \& S. Blanchard, What's in a Meme? The Truth about Investor- State Arbitration: Why It Need Not, and Must Not, Be Repossessed by States, 52 Columbia Journal of Transnational Law (2014), 689.

56 L. Poulsen, The Importance of BITs for Foreign Direct Investment and Political Risk Insurance: Revisiting the Evidence, in K. Sauvant (ed.), Yearbook on International Investment Law \& Policy 2009/2010 (2010). 
where firms take advantage of information asymmetries to lead governments to believe that without a particular incentive, they will not be induced to make decisions that are desirable from the government's point of view. ${ }^{57}$ In any case, predictions (or threats) by those invested in the current system that FDI will not come in the absence of a BIT with investor-state arbitration should be viewed with great scepticism; for example, such predictions were made when South Africa choose to terminate its BITs, replacing them with a new investment law that was enacted in late 2015 (the law curbed drastically access to ISDS); in the year subsequent to the new law, according to UNCTAD, FDI in South Africa surged 38\%. ${ }^{58}$

What about the observed behaviour of states in response to their experience of the costs and benefits of treaty protection? Contrary to Brower's casual observation that "developing countries continue to enter into new treaties offering greater protection to foreign investors than their first-generation treaties" 59 a rigorous empirical study of the "learning" of developing countries from their experience with treaty protection of foreign investors concludes that from the first investor claim against a state on, there is a significantly reduced level of participation in the investment regime. ${ }^{60}$ This is consistent with the overall data examined by UNCTAD — the steep decline in the number of investment treaties signed per year correlates closes with the steep rise in the number of ISDS claims/decisions from 1995 to the present. ${ }^{61}$ But even these data do not fully reflect the extent to which, learning of the costs of treaty protection, states have backed away from entering into these commitments because they do not include renegotiation or new negotiation of treaties with more safeguards for states, without investor-state dispute settlement or with modified rights of investors to bring such cases (for instance India's new model BIT contains a

57 See for other examples and the general problem of information asymmetries in bargaining between states and firms around regulation P. Joskow, Incentive Regulation in Theory and Practice: Electricity Distribution and Transmission Mechanisms, Presentation at MIT (2006). And see generally Laffont \& Tirole, supra note 29.

58 UNCTAD, 'Global Investment Trends Monitor No. 25', 5 (2017), available at https://unctad.org/en/PublicationsLibrary/webdiaeia2017d1_en.pdf (last visited 13 December 2018).

59 Brower \& Blanchard, supra note 55, 701.

60 Poulsen \& Aisbett, supra note 5.

61 UNCTAD, 'World Investment Report 2016, Figure III.3 and III.4', available at http://unctad.org/en/pages/PublicationWebflyer.aspx?publicationid=1555 (last visited 6 December 2018). 
strong exhaustion of domestic remedies clause). ${ }^{62}$ UNCTAD has recorded the magnitude of the shift towards treaties that reflect learning about the actual costs vs. benefits of treaty protection for investors: to take just one example, whereas $12 \%$ of older generation investment agreements included public policy exceptions, $58 \%$ percent of those negotiated or renegotiated between 2012 and 2014 have such provisions. ${ }^{63}$ The vast majority of investment agreements signed in the 2011-2015 period have provisions designed to curb the incentive for opportunistic litigation by investors, constraining forum shopping (denial of benefits), retaining discretion to accept ISDS on a case-by-case basis, or excluding conventional ISDS altogether. ${ }^{64}$ The vast majority exclude umbrella clauses, which, as discussed below, have been used by arbitrators to allow investors opportunistically to overcome contractually bargained constraints on investor protection by converting claims of contractual breach into claims of treaty violation. Of course given what are widely noted as the strong pecuniary incentives of arbitrators to grant jurisdiction, ${ }^{65}$ whether or not these reforms will actually result in a change in the costs to states of treaty protection remains to be

62 Y. Z. Haftel \& A. Thompson, When Do States Renegotiate Investment Agreements? 13 Review of International Organizations (2018), 25-48 (Arguing that states renegotiate investment agreements when they learn new information about the legal and political consequences of their treaty commitments, and that such learning is most likely to take place when states are involved in investor-state dispute settlement cases.); and see, generally, A. Kulick (ed.) Reassertion of Control over the Investment Treaty Regime (2016).

63 UNCTAD, 'Taking Stock of IIA Reform, IIA Issues Note' 1, 9 (2016), available at http://investmentpolicyhub.unctad.org/Publications/Details/142 (last visited 6 December 2018).

64 Ibid., Annex, Tables 1-5.

65 M. Waibel \& R. Wu, supra note 8, observe : "[...] arbitrators lack tenure and a majority of them is selected by the disputing parties. They also differ from judges sitting in national courts who typically have no financial interest in the cases before them.in terms of their incentives. Judges typically receive a flat salary from the government, irrespective of how many cases they hear or which way they decide cases. In arbitration, the financial payoffs for the arbitrators depend on the length or complexity of the arbitration, or the amount under dispute. This opens room for the incentives of judges and arbitrators to differ because ICSID arbitrators are entitled to reimbursement for any reasonably incurred expenses and a fee for each day of the proceedings. [footnote omitted] Since 2008, the fee has been US\$3,000 per day for meetings and other work performed [footnote omitted]. Because there is no fixed fee per arbitration, in principle, the longer the arbitration, the better off financially the arbitrators are. On that basis, it is possible that arbitrators prefer a longer arbitration, holding all else equal, to maximize their fee income. For a full-time legal academic, working for 30 days on an ICSID arbitration could easily 
seen; what they do show however is that the kinds of costs vs. benefits that experience has revealed with respect to treaty protection of investors is generally unacceptable to capital-importing states.

Those in the investment arbitration community like Brower who maintain stubbornly the article of faith that only treaty protection can address adequately investors' (deal-breaking, allegedly) concerns about political risk may only partly be engaged in self-interested adequacy. They may also suffer from not being conversant in the literature on investment location decisions, or contract theory and theory of the firm scholarship on the control of opportunism in long-term or multiple-play relationships between states and firms; it would thus be easy for them to imagine that only treaty protection could manage political risk in a way that is satisfactory to investors. But in fact uncertainty in regulation, while foremost in the mind of attorneys who work and write in this area, may be less significant in investment decisions than factors such as volatility and uncertainty in the general economic environment (as opposed to the regulatory environment). ${ }^{66}$ Still, the arbitration community, for example Brower, points plau-

double their annual income. The position is different for partners in leading private law firms. They often earn more than US\$ 1 million annually. They typically charge up to US $\$ 1,000$ an hour for counsel work (which is several times more than an ICSID arbitrator earns per hour), plus fees for their associates at several hundred dollars an hour. For them, working for 30 days on an ICSID arbitration is unlikely to increase their annual income by more than 10 percent. Relatively speaking, sitting as an ICSID arbitrator is a more attractive proposition in financial terms who are retired government officials or full-time academics." Here I would suggest that the analysis with respect to arbitrators who are senior partners in law firms is incomplete. Often these individuals will rely heavily on juniors or assistants in the firm, who are also billed to the parties to the arbitration. One needs to look not only at how much each such senior lawyer bills in an arbitration vs. their hourly counsel rate but the effect of serving as an arbitrator on overall firm billings, since equity partners share in the profitability of the law firm as a whole, generally. Senior lawyer arbitrators may often delegate the most difficult tasks, which distract from counsel work, to juniors and assistants, making arbitration duties minimally disruptive of their counsel work. In one notorious case, senior lawyer Yves Fortier, according to expert evidence, had an assistant ghost-write the vast bulk of his opinion, billing the parties 1.7 million $\$$ for the services of the assistant (in addition to very substantial billings for himself). Also, multiple experiences as an arbitrator increases the market value of a lawyer as counsel, most likely; one reason why such senior lawyers generally oppose any effort to eliminate the "two hat" practice, whereby arbitrators can serve as counsel even in cases that raise similar legal issues to those they are addressing as an arbitrator in other proceedings-in my view a grotesque conflict of interest.

66 See generally A. Dixit \& R. Pindyk, Investment Under Uncertainty (1994). 
sibly to some sub-set of investment decisions where political risk is a major concern of the investor, but begs the question of why treaty protection is an efficient means of allocating such risk. Of course if the cost to the investor is minimal, investors will welcome all the protections they can get. But this is a different question than whether any given investment decision depends on the granting of treaty protection. Situations of perceived high political risk are in fact those where investors are most likely to seek political risk insurance or contractual bargains with host states. In such circumstances, it is far from clear that treaty protection enhances or enables market approaches to the allocation or reallocation of political risk. Poulsen observes that the existence of a BIT has little impact on premia for political risk insurance, for example. ${ }^{67}$ Indeed, Halabi ${ }^{68}$ speculates that treaty protection could increase the transactions costs of bargaining to an otherwise efficient equilibrium between the investor and the host state. With treaty protection, an investor can attempt a treaty claim to get around a contractual bargain that carefully circumscribes the extent of the host state's commitments to the investor by couching its grievance as a violation of vague treaty norms such as fair and equitable treatment. This is especially acute in the case of investment treaties with "umbrella clauses", which allow a tribunal, if it wishes to adopt such a reading, to elevate any claim of breach of contract into a treaty claim for breach of international law.

Recent work by Arato echoes Halabi's hypothesis that, rather than lowering the transaction costs of market allocation of political risk through contractual bargaining, treaty protection in fact increases these costs, by introducing new uncertainty as to whether the contractual bargain will be disrupted, and giving investors a strategic option to sue under the treaty to overcome contractually bargained limits on recovery for political risk. Arato observes:

It is clearly undesirable for all parties if, ex ante, they cannot predict whether tribunals will give effect to their contractual efforts to opt out of treaty rules ex post. Yet, in the face of treaty silence on the treaty/ contract issue, arbitral jurisprudence has been highly uneven and irregular-often resolving these questions merely on the level of assumptions. [footnote omitted] As a result, the meaning of state contracts in the world of investment treaties remains under a cloud of doubt. But the deeper problem is that tribunals too often slip into an overly rigid and formalistic approach, prioritizing treaty provisions over negotiated

68 Halabi, supra note 37, 305-308. 
contractual bargains. [footnote omitted]... It undercuts the autonomy of the parties, thereby undermining their capacity to allocate risk as they see fit. For the investor, this means risks associated with the viability and profitability of the project. States share those commercial concerns but also bear responsibility for the full range of non-commercial values of import in their respective societies. States negotiating investment contracts thus have to manage the risk that any such project might create future regulatory chill. In other words, the tendency of arbitral tribunals to implicitly prioritize treaty norms over states' and investors' contractual arrangements ultimately reduces both parties' ex ante flexibility to negotiate efficiently. At the same time, this weakens the state's capacity to define the scope of its potential future liability under an investment treaty through contract, which will tend to disincentivize openness to foreign capital in the long run-the very goal that investment treaties are meant to achieve. ${ }^{69}$

In sum, the case for treaty protection of foreign investors as an investment incentive is, to say the least, shaky. 1) It may well be that where investors care most about the host state or a third party assuming political risk, the host state is a weak, failed, or conflict ridden state, or has severe governance and institutional deficits that make FDI unlikely to have the positive developmental effects sometimes identified in the literature (e.g., "resource curse" states);2) there is a plausible argument that treaty protection can increase the value or credibility of other investment incentives by protecting the investor against the "hold-up" situation where the host state, once the investor has sunk considerable costs into asset-specific investments, extracts rents from the investor ex post through regulatory change. Because of the prohibitive transaction costs of writing complete contracts, it is largely impossible to foresee in a contract ex ante every possible regulatory intervention that might be used to "hold up" the investor ex post. 3) Yet it is unclear why treaty protection is indispensable to solving the hold-up problem. A contractual solution may be superior in many instances as the host state can target the protection to investors that it desires to attract; contracts can themselves deal with the incomplete contract problem by including not only fully specified commitments with regard to regulatory change but also general standards typical of investment treaties (e.g., fair and equitable treatment) which the adjudicator is delegated the role of applying on a case-by-case basis. 4) The plethora of empirical studies that attempt to es- 
tablish a correlation between treaty protection and increased FDI suggests that any such relationship is far from clear; studies that purport to show a strong positive correlation have been subject to serious methodological criticism; in fact the entire literature is clouded by methodological problems and controversies. 5) One case where the evidence seems clearly of some positive impact is transitional economies; but in those cases the downside of treaty protection is particularly acute, given the need for regulatory experimentation, the ability to correct mistakes as the state attempts to transition from one economic and social system to another. 6) The literature on investment incentives generally favours the kind of incentives that are targeted. In addition, states should prefer those incentives that result in the generation of benefits to the economy (improved infrastructure, R \& $\mathrm{D} /$ technology transfer, worker training) regardless of whether or how much FDI is actually induced (due to information asymmetries, states cannot know what the exact impact of any given incentive will be on firm behaviour). Obviously, treaty protection for investors is neither targeted nor does it generate separate public goods. 7) Law \& Economics scholars such as Eric Posner point to the fact that in solving the "hold-up" problem, enforceable compensation of private economic actors for regulatory change creates a democracy problem-the incumbent government makes a longterm commitment to an investor, the cost of which may be borne largely or entirely by a subsequent government, perhaps of a different political orientation. The incumbent makes it costly for a subsequent government to correct its mistakes or reverse benefits that may have been handed out due to cronyist or interest group capture politics. But if an investment treaty regime can be designed so that only regulatory changes that are opportunistic hold-ups are disciplined, such that states can have confidence that adjudicators will not end up creating liability for other regulatory changes, then the regime may result in more not less optimal policy outcomes.

\section{B. A substitute for domestic rule of law}

A different line of justification for treaty protections for foreign investors is that these address and provide a remedy for inadequate domestic governance arrangements, lack of rule of law and protection of property rights. These latter are often regarded in the mainstream development and gover- 
nance literature as important for development and economic growth. ${ }^{70}$ Even if the participation of foreign capital in domestic economic growth is not dependent upon some form of insurance against the negative consequences of regulatory change, it is argued that it does require basic protections against arbitrary, discriminatory, or confiscatory behaviour of states that is not curbed by well-developed constitutional or administrative law norms, or where there do not exist effective, impartial, non-corrupt domestic judicial institutions to enforce such norms. Super-arbitrators such as Christoph Schreuer and Jan Paulsson, often emphasize this rationale. According to Schreuer, "[i]t is a sad fact that many countries lack a truly independent judiciary." ${ }^{71}$ Indeed, the fundamental obligations common to almost all BITs of compensation for expropriation, fair and equitable treatment, and national treatment, if interpreted narrowly rather than broadly could be considered as a de minimis "rule of law/property rights" regime that applies to foreign investment, rather than as insurance against regulatory change. Jan Paulsson defends treaty protection and investor-state arbitration, as in the NAFTA, as among the "enclaves of justice" in a world where the rule of law is little respected in practice. ${ }^{72}$

In reality, there are three kinds of rule of law rationale that are often conflated. One strand of the rationale is the "enclave" one; countries with serious rule of law and governance deficits need FDI, and treaty protection provides the "enclave" that makes that FDI possible. This is not ultimately so different from the hold-up theory of investment protection. However, delay, corruption, and incompetence in adjudication and administration could well create considerable costs for the investor even when they are not being deployed as part of a conscious hold-up strategy by the host state authorities. The second strand of the rule of law rationale is that by undertaking treaty commitments, states will have incentives to improve the rule of law and governance generally in order to avoid liability under the treaty. Thus the treaty commitment will cash out in terms of wider social benefits (in addition to the FDI that is facilitated or induced by providing the investor with an "enclave"). The third strand in the rule of law rationale is in

70 See for example the influential paper by D. Kaufman, et al., Governance Matters VII: Aggregate and Individual Governance Indicators 1996-2008, 4978 World Bank Policy Research Papers (2009).

71 C. Scheuer, Do We Need Investment Arbitration?, in J. E. Kalicki \& A. JoubinBred (eds.), Reshaping the Investor-State Dispute Settlement System (2015), 879, 883.

72 J. Paulsson, Enclaves of Justice, 29 University of Miami Legal Studies Research Papers (2007). 
reality a depoliticization rationale; if there is a fundamental ideological divide between home and host countries about property rights and basic legal norms (the Cold War-type situation), a compromise that offers depoliticization of investment disputes is to allow the host state (communist or command-and-control oriented) to keep its own ideology and legal system, while offering the capitalist investor the kinds of protections expected in the West.

With respect to the "enclave" rationale, the literature raises serious doubts about the capacity of treaty protection to induce FDI in the absence of more general improvements in the rule of law and governance. ${ }^{73}$ There is evidence that BITs "only have a positive impact on FDI flows as complements to-not substitutes for-the domestic investment environment... Poor countries cannot bootstrap an aggressive program of entering into BITs into a major increase in FDI. They cannot avoid the hard work of improving their own domestic environment for investment." ${ }^{34}$ The same study further concludes that even in those countries that are on a positive governance trajectory and enter into BITs, only a very small percentage of the additional FDI can be attributed to the BIT as opposed to domestic governance improvements. A further consideration is that, as already noted, the quality of domestic institutions seems to matter for whether FDI leads to economic growth and development. This suggests that if the rule of law is weak in a particular state, the logical answer is to strengthen the rule of law there, not simply insulate foreign investors from the effects of bad governance. ${ }^{75}$

With regard to the rule of law rationale that suggests treaty commitments incentivize the host state to make general improvements in the rule of law and governance, it is to be noted that investment agreements are never accompanied by technical assistance, or measures to actually help developing or transitional countries improve judicial or other domestic governance institutions; here, for example the new WTO Trade Facilitation Agreement (that deals with management of customs and border controls) stands in stark contrast, where commitments of developing countries are matched to their capacities and to technical assistance available to enhance

73 Jude \& Levieuge, supra note 31.

74 J. Tobin \& S. Rose-Ackerman, When BITs Have Some Bite: The Political-Economic Environment for Bilateral Investment Treaties, 6 Review of International Organizations (2011), 1.

75 S. D. Franck, Foreign Direct Investment, Investment Treaty Arbitration and the Rule of Law, 19 McGeorge Global Business and Development Law Journal (2007), 337, 365-369. 
capacities. ${ }^{76}$ By contrast, in the case of investment treaties, there is evidence that protecting one constituency, foreign investors, from the impact of weak rule of law actually reduces pressures for more general salutary governance reforms. ${ }^{77}$

In sum, from an economic development perspective, BITs, where they reduce pressure for domestic governance reforms, are doubly harmful: they make less likely the reforms that really matter for increases in FDI, and that also most matter in terms of the ability of the state to exploit FDI as a ladder to economic growth and development. And we must not forget that a state undertaking major reform of domestic institutions may well need to engage in regulatory experimentalism: the resulting flux or instability in the regulatory framework, necessary to get to the right institutions, could itself lead in some instances to claims under the BIT, thus adding considerable costs and risks to needed governance reform.

With respect to the depoliticization strand of the rule of law rationale, where a state is ideologically or otherwise opposed to Western conceptions of the rule of law and protections of property and contract rights of the kind typical of mixed economies in the West, the case for treaty-based investor protection is strongest. The sovereignty of the host state is protected; it can maintain a domestic political, economic, and legal system as hostile to capitalism and liberal legalism as it likes, provided it compromises in its international economic relations and agrees that foreign investors from different systems can have some basic protections that in those systems would be seen as fair and legitimate. One can imagine such a compromise being in the interests of both sides.

Notably, outright dictatorships have rarely objected to paying investorstate arbitral awards. As Sattorova observes, ${ }^{78}$ authoritarian regimes such as Erdogan's Turkey, Uzbekistan, and Kazakhstan (the latter two "resource curse" autocracies) ${ }^{79}$ seem quite satisfied with the existing system of treaty protection for foreign investors (and this despite Kazakhstan having to pay

76 See A. Eliason, The Trade Facilitation Agreement: A New Hope for the World Trade Organization, 14 World Trade Review (2015), 643.

77 T. Ginsburg, International Substitutes for Domestic Institutions, 25 International Review of Law and Economics. (2005), 107.

78 M. Sattorova, Reassertion of Control and Contracting Parties' Domestic Law Responses to Investment Treaty Arbitration: Between Reform, Reticence and Resistance, in A. Kulick (eds.), Reassertion of Control Over the Investment Treaty Regime (2016), 56-63.

79 See H. Meissner, The Resource Curse and Rentier States in the Caspian Region: A Need for Context Analysis, 113 German Institute of Global and Area Studies Working Papers (2010). 
multiple awards against it, tens of millions of dollars). Foreign investment allows these regimes to exploit resource rents and resist domestic pressures for democratization/rule of law reforms; treaty protection assuages concerns of foreigners in a situation where rule of law is absent or largely contingent on the will of autocratic rulers, while allowing the autocratic rulers a free hand domestically.

But putting aside these cases, the way the world has evolved since the fall of Soviet communism has weakened or qualified the rule of law rationale for treaty-based investor protections. First of all, the number of states that reject in principle basic "Western" protection of contract and property rights (subject of course to these having been overridden for legitimate policy objectives) and some version of liberal rule of law have declined considerably. More and more states are democracies where government at least purports to be accountable to the people. While there may be governance deficits in many of these countries and problems like corruption and administrative incompetence, as noted above, good policy would suggest that these are best dealt with, not through insulating foreign capital from these problems, but maximizing the incentives for general domestic reforms. At the same time, negotiations such as TTIP and CETA have driven home, as have for example rulings adverse to Canada under the NAFTA, that treaty-based investor protections can be used aggressively by investors against states where there is no general rule of law deficit. Of course, some of the democracies in question are fragile democracies, and there is serious evidence of persistent rule of law deficits in some established democracies, ${ }^{80}$ but the case that, through international law, foreign interests alone should be given a get out of jail free card from these problems seems, to say the least, flimsy.

In fact recent empirical work confirms the dramatically declining salience of the "rule of law" rationale for treaty protection, especially after the stabilization of the post-Communist transition. Schultz and Dupont analyzed a data set of 500 claims from 1972 to 2010. They found: "investment arbitration appears to have been used as a replacement for dysfunctional domestic courts in countries with a weak rule of law tradition until the mid-to-late 1990s, but since then it seems to have served this function

80 A. von Bogdandy \& M. Loannidis, Systemic Deficiency in the Rule of Law: What it is, What Has Been Done, What Can Be Done, 51 Common Market Law Review (2014), 59. 
increasingly less." ${ }^{11}$ (It should be noted that the Schultz and Dupont study included both treaty and contract claims in international investment arbitration.) This raises a further question about the rule of law, which brings us back to the issue of why contractual bargaining is suboptimal. Investors can protect themselves in dealing with a state that is deficient in the rule of law through a contract that specifies international arbitration as the dispute settlement forum and enforcement gateway. Thus even where absence of rule of law presents a high political risk, it is not clear why treaty protection would be essential. Also, MIGA, the political risk insurance arm of the World Bank, insures projects in countries with high political risk, such as failed or weak states or conflict states where the rule of law failure may be extreme. ${ }^{82}$

\section{International Justice}

We could regard proper treatment of aliens as an absolute international obligation: absolute, in the sense that it is based not on a theory about a domestic good governance deficit but rather one that sees such proper treatment as required by underlying values of international law- the comity of nations, the ancient ideal of hospitality toward foreigners who come to a country with a peaceful benign intent. ${ }^{83}$ In fact, basic international norms of fairness and justice in the treatment of aliens have long been established in customary international law. Provided that protections such as fair and equitable treatment, national treatment, and compensation for expropriation are applied in a strict or narrow way, they simply reinforce human rights-like elements to longstanding notions in customary law that unjust, discriminatory, or arbitrary treatment of aliens engages state responsibility under international law. ${ }^{84}$ Commerce has long been recognized as one of the fundamental forms of peaceful intercourse among na-

81 T. Schultz \& T. Dupont, Investment Arbitration: Promoting the Rule of Law or Over-Empowering Investors? A Quantitative Empirical Study, 25 European Journal of International Law (2015), 1147, 1149.

82 World Bank Multilateral Investment Guarantee Agency, 'World Investment and Political Risk Report' (2010), Chapter 2, Investment and Political Risk in Conflict-Affected and Fragile Economies.

83 V. Chetail, Sovereignty and Migration in the Doctrine of the Law of Nations: An Intellectual History of Hospitality from Vitoria to Vattel, 27 European Journal of International Law (2016), 901.

84 T.G. Nelson, Human Rights Law and BIT Protection: Areas of Convergence, 1 Transnational Dipsute Management (2013). 
tions. While, as $18^{\text {th }}$ century thinkers like Montesquieu and Kant realized, there could be exploitative forms of commerce that should be justifiably regulated or controlled, treating foreign economic actors, including corporations, with basic fairness and due process seems reasonable-if they behave in a manner compatible with domestic laws and customs. ${ }^{85}$ In addition, as discussed in the historical overview, the obligation that direct expropriation be compensated has become an established norm of customary international law, albeit after a long battle between developed and developing countries as to whether the compensation should be based on market principles alone or, reflects other social and economic considerations. Generally, the developed world won this battle, in that tribunals awarding compensation have been convinced that "just" or "adequate" compensation requires awarding the full market value of the property taken. The question of whether however full market value compensation can be considered as required by "justice" rather than simply as neo-colonialism abetted by the international legal community, will be considered in a later section of the paper.

The morphing of customary norms into treaty protections need not be viewed as a neoliberal conspiracy, but rather as merely one instance of the modernization and codification of custom, as occurs in many other areas, influenced both by the role of commerce in the contemporary world as well as post-Westphalian conceptions of the justified protection of nonstate-actor interests by international norms, and also the imposition of international responsibilities on non-state actors (the US Alien Tort Claims Act; international criminal justice). ${ }^{86} \mathrm{~A}$ reflection of this kind of rationale is the attempt by the United States, Canada, and some other states, through interpretive understandings, to require that investor-state tribunals read norms in investment treaties such as fair and equitable treatment as limited to the customary law of protection of aliens as it existed before the specific rationales for investor protections discussed above had any play, and that compensation for takings be generally limited to direct takings and not extend to general non-discriminatory regulatory measures of equivalent economic effect (see the language in the current US model BIT on this).

85 See generally the contributions in O. Asbach et al., Der moderne Staat und 'le doux commerce': Politik, Ökonomie und internationale Beziehungen im politischen Denken der Aufklärung (2014).

86 See R. Teitel, Humanity's Law (2010), for a magisterial account of these developments. 
With respect to fair and equitable treatment, freezing customary international law at the state of law of diplomatic protection of aliens before the investment regime emerged is a crude and distorted way of trimming investor protection to what is defensible on international justice concerns, because in fact the human rights revolution and normative developments that have been encapsulated by my colleagues Benedict Kingsbury and Richard Stewart, under the rubric of global administrative law, ${ }^{87}$ have extended the conception of basic fairness to aliens to include not only explicit discrimination and egregiously abusive treatment, but also some degree of administrative fairness and the notion of due process in a regulatory state where judicial review of the way in which administrative agencies treat private economic actors is considered normal.

A difficulty with international justice as a rationale for treaty-based investor protection is that, in relying on post-Westphalian human rights revolution-based concepts of an international legal order that protects directly not only state interests but those of other actors, the justice argument opens the door to the question of why in this post-Westphalian human rights/humanity law world, one would asymmetrically require that international justice be available for the investor and not also require, reciprocally, that the investor be subject to requirements of international justice, as reflected in codes of corporate responsibility, heavily influenced by human rights, but which remain largely soft international law. ${ }^{88}$ It seems only reasonable that the ability of the investor to invoke international justice should be contingent on the investor's willingness to subject its own conduct to the norms of international justice. To a limited extent, and depending upon the language of the particular treaty, investment tribunals are able to entertain counter-claims by the host state; but even this constrained possibility of counterclaims depends upon the availability of applicable legal norms that reflect international standards of justice for corporations. And of course directly affected actors-members of the local community, indigenous groups - as well as advocacy groups have no standing to claim or counterclaim at all in investor-state arbitration.

87 For the application of Global Administrative Law to the investment treaty context, see B. Kingsbury \& S. Schill, Investor-State Arbitration as Governance: Fair and Equitable Treatment, Proportionality, and the Emerging Global Administrative Law, 6 Institute for International Law and Justice - New York University Law School - Working Papers (2009).

88 This issue is well-explored in K. Miles, Chapter 6: Paths Towards a Reconceptualised International Law on Foreign Investment, in K. Miles, supra note 16. 
The response of those who are invested in the current system, such as Charles Brower, is that states have lots of ways in which they can protect the interests and rights of their citizens with respect to foreign investors. ${ }^{89}$ Investors are supposedly entitled to more than the protection of their home governments (diplomatic protection) and deserve a direct right of action, while other interests-workers, environmentalists-have to rely on the home state for protection. At least with respect to the claim of a power imbalance that hugely favours host states, this claim has been rather decisively refuted by recent political economy scholarship; thus, in new work, Aisbett and Poulsen find that 'foreign firms' experiences at the hands of host governments tend to be as good, or better, than those reported by their domestic counterparts." ${ }^{90}$ Moreover, "the poorer a country, the more exposed it is to pressure by foreign governments and international organizations demanding special attention to the needs of multinationals." ${ }^{11}$ Defenders of the existing system, such as Charles Brower, respond that the interests or stakeholders have the protection of their own state. But the whole logic of the shift from diplomatic protection to investor-state arbitration was the inadequacy of diplomatic protection and the right of the affected actor, the investor, directly to seek justice at the international plane. Why should underrepresented, minority, or disempowered groups or interests in a state have to rely on the protection of the state alone, while powerful multinationals can directly access international justice? (The ignorance of the arbitration community of international human rights is reflected in the notion that Brower puts about that human rights courts are asymmetrical, implying that they don't protect private property interests of foreign investors; yet there is an extensive jurisprudence on expropriation in the European Court of Human Rights for example.)

\section{Anti-Protectionism}

In the international trade regime, as exemplified by the WTO, non-discrimination norms are well-established and widely accepted as a fundamental element of the legal framework, subject to general exceptions that

89 Brower \& Blanchard, supra note $55,712-713$, dogmatically asserting that "the actual power imbalance glaringly favors [sic] host states [...]”.

90 A. Aisbett \& L. Poulsen, Relative Treatment of Aliens: Firm-level Evidence from Developing Countries, 1 University of Oxford - Global Economic Governance Programme - GEG Working Papers (2016).

91 Ibid., 18. 
protect legitimate public policies. In fact, critics of ISDS who have warned of the risk to policy space or the right to regulate have been primarily addressing those investment agreements that lack the kinds of exceptions one finds in the WTO in the case of non-discrimination norms with respect to trade in goods and services. Extending non-discrimination from trade to investment, provided appropriate safeguards are available for legitimate domestic policies, seems only logical given that global supply chains operate typically today through some combination of trade (external contracting across borders) and investment (internal contracting). ${ }^{92}$ Bown and Horn note: "parties [to a regional trade agreement] might benefit from coordinating their concessions in the trade and investment areas. The most immediate case where such gains could be reaped seems to be motivated by the rise of global supply chains; undertakings relating to trade liberalization for goods and services would occur alongside those relating to investment." 93

Existing WTO rules, including those in the Trade-related Investment Measures (TRIMs) Agreement, only discipline regulatory treatment of foreign investors where such regulatory treatment (for instance domestic content or trade balancing requirements) results in discrimination in the trade in goods. An exception is the General Agreement on Trade in Services (GATS), where non-discrimination rules apply to so-called mode 3, provision of services through a commercial presence in the territory of the other WTO Member. However, in the case of National Treatment under GATS, as a general matter, the obligation only applies where Members have sched-

92 See the discussion of the two unbundlings of globalization in R. E. Baldwin, '21st Century Regionalism: Filling the Gap between 21st Century Trade and 20th Century Trade Rules' (2011), available at http://dx.doi.org/10.2139/ssrn.1869845 (last visited 6 December 2018) "The heart of 21 st century trade is an intertwining of: 1) trade in goods, 2) international investment in production facilities, training, technology and long-term business relationships, and 3) the use of infrastructure services to coordinate the dispersed production, especially services such as telecoms, internet, express parcel delivery, air cargo, trade-related finance, customs clearance services, etc. This could be called the trade-investment-services nexus.."

93 Bown \& Horn, supra note 10, 6. See also S. Kim et al., 'Firms' Preferences over Multidimensional Trade Policies: Global Production Chains, Investment Protection and Dispute Settlement Mechanisms' (2017), available at http://web.mit.edu/ insong/www/pdf/conjoint.pdf (last visited 6 December 2018) (finding that investment protection is the most salient trade policy dimension for firms who are most deeply integrated into global production networks. In addition, strong dispute settlement procedures are most valued by exporters who are not central to global supply networks). 
uled a particular sector; general public policy exceptions apply as well as limitations that any Members may have included in their schedules.

If we view external contracting (trade) and internal contracting (investment) as alternatives ways of operating transboundary economic activity ${ }^{94}$ that are often combined, regulatory protectionism ${ }^{95}$ would operate in a similar way in both instances to increase costs to consumers and distort the allocation of resources. Helpman has noted the considerable interdependency of trade and FDI: "Evidently, foreign direct investment can feed foreign trade in complicated ways, making trade and FDI interdependent. On the one hand, patterns of FDI influence patterns of trade. On the other hand, the profitability of different forms of FDI depends on the profitability of various trade options. As a result, a firm's choices of multinational integration strategies depend on trade opportunities. Under the circumstances, trade and FDI become inseparable twins." ${ }^{\prime 6}$

Despite these observations, unlike the case with the trade regime, there is little economic literature that makes the case for investor protection as a discipline on "regulatory protectionism." Notably, however, Stiglitz-who is generally sceptical of investor protection through treaties-accepts the value of a non-discrimination norm with respect to investment. ${ }^{97}$

My own initial experiences with the investment regime came through involvement (on behalf of investor's counsel) in disputes where discriminatory treatment was an essential element in the case against the host state. In these claims, the investor was, fundamentally, demanding treatment as favourably as that accorded to similarly-situated domestic economic actors (taking account of legitimate policy objectives). This is, of course, entirely consistent with the Calvo Doctrine, the position that foreign investors are entitled to as good a standard of treatment as that accorded to similarly situation domestic investors, but not more. Overall, arbitrators have seemed to be more comfortable in adjudicating these situations based on grounds

94 See E. Helpman, A Simple Theory of International Trade with Multinational Corporations, 92 J. Pol. Econ. (1984), 451; G. Grossman \& E. Helpman, Outsourcing versus FDI in Industry Equilibrium, 9300NBER Working Papers, (2002).

95 See A. Sykes, Regulatory Protectionism and the Law of International Trade, 66 University of Chicago Law Review 1, 5 (1999): “[...] regulatory protectionism is economically inefficient in part for the same reasons that protectionism of any sort is inefficient. Protectionism draws high cost domestic firms into the market while excluding low cost foreign firms, and it prices out of the market some consumers who would be willing to purchase goods at a price exceeding the marginal cost of production of efficient suppliers..

96 E. Helpman, Understanding Global Trade (2011), 129.

97 Stiglitz, supra note 22, 548-550. 
other than discrimination. They have seemed determined to reinforce the investment regime as a system that gives investors entitlements beyond those that like domestic actors would have. It is in any case odd that what seems the clearest economic rationale for investor protection accounts for very little of the litigation. According to data from UNCTAD, investor-state arbitral tribunals have found to date all-told 150 breaches of investment treaties, but only 8 of these were breaches of National Treatment, the obligation not to discriminate against foreign investors relative to domestic economic actors. ${ }^{98}$ This represents an extremely small fraction of cases, and indeed (in a system where often investors' counsel alleges as many violations of different provisions as they can) it is remarkable that National Treatment violations constituted only 108 of 469 breaches that investors claimed for.

In sum, while the strongest theoretical economic rationale for investment protection is the discipline of regulatory protection, the regime seems to have a minimal impact on discrimination, as reflected in the claims to date of investors and the findings of tribunals. Of course this does not mean that some particular set of discriminatory policies that affect foreign investors is not costly and deserving of effective international discipline. In a 2013 study, for example, Hufbauer et al. quite plausibly single out local content requirements: they estimate that " $\$ 1.1$ trillion in trade was impacted by LCRs in 2010, almost 6 percent of total global trade...As a conservative but speculative guess; we would say that the tariffequivalent is 10 percent ad valorem." ${ }^{99}$ While they conceptualize the costs in terms of trade protection, one could equally consider the costs to efficient allocation of production that arise from the disruption of supply chains of investors through these requirements. While there is a live debate about the justification of such requirements on, for example, infant industry grounds (particularly with respect to clean energy), there are also strong arguments that they constitute a highly inefficient way of developing domestic industrial capacity. ${ }^{100}$ Another kind of discrimination that has been characteristic of the economic and industrial policies of a wide number of countries is the screen of foreign direct investment and explicit limits on

98 UNCTAD, 'Investment Dispute Settlement Navigator', available at http://investm entpolicyhub.unctad.org/ISDS (last visited 6 December 2018).

99 G. Hufbauer et al., Local Content Requirements: Report on a Global Problem (2013).

100 S. Stone, J. Messent \& D. Flaig, Emerging Policy Issues: Localisation Barriers to Trade, 180 OECD Trade Policy Papers (2015), available at http://dx.doi.org/10.17 87/5js1m6v 5qd5j-en (last visited 6 December 2018). 
the extent to which foreign interests can participate in the economy, especially in certain sensitive sectors (defence, telecommunications, media, etc.). ${ }^{101}$

These types of discrimination are captured by National Treatment norm, only where the treaty provision in question extends to the establishment of the investment; the United States' BITs do (as do those of Japan now) but many others do not. Instead, in many treaties National Treatment is only required once an investment has been permitted by the host state to establish itself in that country. But it is not only the absence of an establishment right in many investment agreements that has made the investment regime insignificant in the discipline of discriminatory entry barriers for foreign investors-there are structural considerations as well. The discipline of the investment regime operates through making claims of extremely large monetary damages, which "justify" the large sums taken by arbitrators and counsel. But it is understandably difficult to get a large damage award where no investment has yet been made; there are no or few cognizable losses, and in any case the damages theory that dominates is an expectations theory that rewards the investor based on present future value, i.e., what revenues the venture would have generated but for the wrongful conduct. Where an investment has yet to be established, expectation damages (future profits) are unlikely to be awarded, given the large speculative aspect of determining whether and to what extent the business would have succeeded. This all being said, there is the even more difficult question of evaluating how much weight should be given for justifications for the kind of discriminatory restrictions at issue, especially where matters such as national security and national cultural self-determination are raised. UNCTAD's 2016 World Investment Report observes a general decline in the incidence of restrictions specifically targeting foreign investors, while those related to national security concerns have increased. ${ }^{102}$

\section{Alignment and Misalignment of the "Main" Substantive Treaty Norms with Rationales for Investor Protection}

It should first of all be recalled that I have stylized the norms considered to allow the construction of a simplified framework for analysis; they are:

101 See M.J. Trebilcock, R. Howse \& A. Eliason, The Regulation of International Trade (2013), 575-580.

102 UNCTAD, supra note $61,90-100$. 
compensation for expropriation, FET and NT, and (somewhat less common) an umbrella clause converting commitments of the host state by the investor, including through contract, into treaty claims.

\section{A. The incentive rationale}

The analysis above led to the conclusion that treaty protection for investors is unlikely to be an efficient form of investment incentive. The one possibility that seems at least plausible is that treaty protection can enhance the efficiency of other investment incentives, increasing their value to the investor by offering protection from the hold-up problem, where once the investor has sunk considerable costs into an asset-specific investment in the host state, the latter takes some regulatory action that is sub-optimal from the perspective of domestic welfare but extracts rents from the investor. On this theory, treaty protection addresses the impossibility or prohibitive transactions of writing a complete contract that would specify ex ante and discipline all possible regulatory actions that the state could use for such opportunistic rent extraction.

The case law to date in investor-state arbitration shows that in applying the main norms of compensation for expropriation and FET particularly, arbitrators have often felt comfortable in constructing, based on the circumstances of each case, a conception of the investor's reasonable or legitimate expectations about what kinds of regulatory changes the treaty provides insurance against. Umbrella clauses give the tribunals an additional tool for sweeping into the net commitments that have established reliance interests of the investor, where the facts do not align so easily with a notion of inherently unfair conduct of the state, or are less tractable to a "regulatory takings" analysis. Nevertheless, the approaches of different tribunals as to how restrictive or permissive these norms are of various kinds of regulatory changes have doubtless influenced how they completed the contract in individual instances. Some tribunals, even where there is no police powers or public policy exception in the treaty, have suggested that an investor should never reasonably expect that they are insured against regulatory change that reflects legitimate, justified public policy concerns and is nondiscriminatory (Waste Management); others (Metalclad for instance) have suggested that what matters, at least for compensation for expropriation, is simply the economic effect on the investor of the regulatory change or that there is a general presumption an investor is entitled to a stable regulatory framework (!) (Tecmed). This uncertainty about outcomes is important to understanding the various economic effects of treaty-based investor protec- 
tion, but it could be understood significantly as a product of a choice of dispute settlement mechanism (ad hoc arbitration) without precedent and appeal, and so will be examined in the next section of the paper on choice of dispute settlement mechanism.

Critics of the investment regime point to the vague and open-ended nature of the expropriation and FET provisions in investment agreements as a problem in terms of guaranteeing domestic policy space, and some states such as Canada have responded by trying to narrow the range of interpretations of these provisions that tribunals may adopt. However, precisely because the problem of incomplete contracts here is that one cannot specify ex ante the full range of regulatory actions that might hold up the investor, only open-ended legal disciplines that give the adjudicator discretion to determine ex post that a particular regulatory intervention, in the circumstances, reflects a hold up of the investment is truly responsive to the inability to write complete contracts to control opportunism. Ex ante uncertainty about policy space is simply the corollary of the strategy of delegating to arbitrators the task of completing the contract ex post, as it were. This explains what often seems like the dialogue of the deaf between critics and defenders of the investment regime. The very structural features of the system that are seen to make it effective in protecting investors against host state opportunism - the hold-up problem - at the same time result in ex ante uncertainty about the policy space available to states under open-ended treaty norms. In other words, trying to specify ex ante through interpretative understandings or revised substantive obligations in treaties what situations represent "hold-up" scenarios and what do not is unlikely to be effective. However, having a general public policy exception in the treaty, which instructs the adjudicator to focus on whether the policy intervention can be understood as necessary for or proportionate to a legitimate public policy objective can, if such an exception is drafted properly and interpreted consistently over time and with sensitivity to the political preferences of the regulating state, address the risk of regulatory chill or liability in situations that are not really hold-ups, i.e., where the state is acting for reasons other than opportunistic rent-extraction. This will now be elaborated.

It should be recalled that, ideally, controlling the hold-up problem should, as the analysis of Aisbett and Bonnitcha suggests, ${ }^{103}$ lead to com-

103 See especially on the analysis of substantive treaty norms J. Bonnitcha \& E. Aisbett, An Economic Analysis of the Substantive Protections Provided by Investment Treaties, in K. Sauvant (ed.), Yearbook on International Investment Law and Policy 2011-2012 (2013), 682. 
pensation only for socially inefficient (opportunistically rent-grabbing) regulation. This is similar to the concern of Posner, for example, ${ }^{104}$ that in addressing the hold-up problem, commitments to pay damages to private actors create a different problem of making efficient regulatory change more costly, and in particular making it difficult for a new government to correct regulatory errors of a previous one, or to respond to preferences of the voters who had elected it.

One question is whether a NT obligation standing alone might be sufficient to identify hold-up situations, which are analogous to protectionist regulations in the case of international trade. However, some of the elements that some tribunals have found present in the FET norm (due process, transparency) may be important in assessing whether the regulation is legitimate as opposed to rent-grabbing opportunism; yet as Bonnitcha and Aisbett note, if interpreted so as to protect very broadly investor expectations, FET could result in forcing a host state to compensate even for efficient regulatory changes. Requiring compensation at least for direct takings seems consonant with the hold-up rationale, given that such expropriation usually involves a transfer of wealth to the government. However, as Bonnitcha and Aisbett have emphasized, there could be situations where a taking is the most efficient instrument given the legitimate public policy purpose. One example could be reversing a failed experiment in privatizing services such as water and electricity, where the result had not generated the required public goods. The need to compensate the investor would take away funds for other crucial legitimate purposes, there being little guarantee that the tribunal will exercise its discretion to complete the contract ex post only to impugn inefficient rent-extracting regulatory changes, as opposed to those that may enhance. This would especially be the case where tribunals tend to adopt a legitimate expectations view of FET and an economic effects view of whether a regulatory change constitutes "expropriation"-in neither case is there an explicit consideration of whether the regulatory change is closely connected to legitimate public policies of the host state; many tribunals in fact underline that whether or not a regulatory intervention is for a legitimate public purpose is irrelevant to the requirement of compensation.

Here, I believe it is instructive to consider how the GATT/WTO multilateral trade regime has attempted to solve a problem of opportunism analogous to the hold-up problem with regard to investors. Under the WTO regime, states make legally binding commitments to limit tariffs and other 
border impediments to market access. However, there is, in principle, an almost unlimited number of domestic regulatory actions that a WTO Member might take that could negatively affect the promised market access through bindings with respect to border measures, i.e., which would have tariff-like effects in terms of affecting the relative competitiveness of domestic vs. imported products. One way the GATT addresses this is through affording the possibility of so called "Non-Violation Nullification and Impairment Complaints" (NVNI), where the complainant state has the possibility to demand compensation if subsequent policies of the respondent state undermine the complainant state's reasonable or legitimate expectations as to what market access it would gain from the respondent state due to specific binding concessions of the latter in previous negotiations. This said, establishing objectively defensible expectations against a particular historical baseline of concessions have proven extremely difficult, and the window for NVNI has been made very narrow through jurisprudence. Instead the main jurisprudential response to the issue of ex post regulatory actions that affect the market access value of binding treaty commitments that has emerged in the WTO is to have a NT obligation that is interpreted such that there is a prima facie violation where a domestic measure negatively affects the competitive opportunities of imported products relative to domestic like products. This reading of the NT obligation is coupled with a robust general public policy exception that allows a WTO Member to justify its measure as directed towards a legitimate public policy purpose. Through appellate jurisprudence, an elaborate structure has emerged for the evaluation of regulating states' arguments and evidence that their measure is properly fitted to contribute to the achievement of legitimate public policy goals. ${ }^{105}$ The delicate task of controlling opportunism (cheating on market access commitments through domestic policy interventions) while not interfering with legitimate policies that enhance social welfare as understood by the host state centres on the deployment of this justificatory structure on a case-by-case basis.

As noted above, according to UNCTAD data, there has been a dramatic trend towards the inclusion of general public policy exceptions in investment agreements, with $58 \%$ of recently negotiated agreements containing such clauses, as opposed to about $10 \%$ in the case of earlier era agreements. This suggests, in Poulsen's sense, "rational learning"-it is a response to ex-

105 I have elaborated this structure in other recent scholarship. R. Howse, The World Trade Organization 20 Years On: Global Governance by Judiciary, 27 European Journal of International Law (2016), 9. 
perience with the way in which arbitrators have exercised discretion under anti-expropriation and FET where unguided by a public policy exception (although some tribunals have brought in conceptions of "police powers" and legitimate regulation in applying such provisions, many others have not).

A good example of such a general public policy exceptions provision is the one in India's 2016 model BIT, which reads as follows:

Nothing in this Treaty precludes the Host State from taking actions or measures of general applicability which it considers necessary with respect to the following, including:

(i) protecting public morals or maintaining public order;

(ii) ensuring the integrity and stability of its financial system, banks and financial institutions;

(iii) remedying serious balance-of-payments problems, exchange rate difficulties and external financial difficulties or threat thereof;

(iv) ensuring public health and safety;

(v) protecting and conserving the environment including all living and non-living natural resources;

(vi) improving working conditions;

(vii) securing compliance with the Law for the prevention of deceptive and fraudulent practices or to deal with the effects of a default on a contract;

(viii) protecting privacy of individuals in relation to the processing and dissemination of personal data and the protection of confidentiality of individual records and accounts; or

(ix) protecting national treasures or monuments of artistic, cultural, historic or archaeological value.

Yet another matter, however, is whether full market value is the appropriate measure of compensation. Full market value damages give investors litthe incentive to engage in conduct that mitigates or reduces the risks that problems will emerge-commercial, social and environmental-that may ultimately lead to an expropriation. Law \& Economics scholars who consider the appropriate level of damages a state should pay for breaking a commitment to a private economic actor agree that expectation or full market value damages are not socially efficient (with Posner taking the most radical view that judicially enforceable damage payments of any 
amount are apt to reduce social welfare). ${ }^{106}$ India's 2016 model BIT allows for the downward adjustment of damages from full market value to control for moral hazard on the investor side. It provides that the following factors (among others) may lead to a mitigation of full market value compensation:

(e) options available to the Investor or Investment to mitigate its losses, including reasonable efforts made by the Investor or Investor towards such mitigation, if any; (f) conduct of the Investor that contributed to its damage; ( $\mathrm{g}$ ) any obligation the Investor or its Investment is relieved of due to the expropriation; (h) liabilities owed in the Host State to the government as a result of the Investment's activities; (i) any harm or damage that the Investor or its Investment has caused to the environment or local community that have not been remedied by the Investor or the Investment; and ( $\mathrm{j}$ ) any other relevant considerations regarding the need to balance the public interest and the interests of the Investment.

\section{B. The rule of law substitute rationale}

From the historical perspective outlined at the start of this essay, it is understandable that FET and compensation for expropriation would be aligned with the rule of law substitute rationale. The content of these norms, especially when FET is interpreted as requiring non-discrimination, impartial and independent judicial institutions, due process and/or regulatory fairness, seems to represent the minimum legal protection that (in the first instance, developed/Western countries) consider as needed for the operation of a market economy yet are missing in states that have alternative political and economic ideologies. The latter accepting to apply these norms to foreign investors is a political and diplomatic compromise that manages some degree of economic interdependence between rival systems. What, however, of the more common post-Cold War case of governance deficiencies that come from the underdeveloped or transitional fea-

106 Posner, supra note 50; Wickelgren, supra note 49. Hadfield suggests that limiting recovery to reliance damages (compensation for losses/sunk costs) is a correct solution. G.K. Hadfield, Of Sovereignty and Contract: Damages for Breach of Contract by Government, 8 Southern California Interdisciplinary Law Journal (1999), 467. I understand from Joseph Stiglitz that his view is also that damages under investment treaties should be limited to reliance damages or loss recovery. 
tures of the country in question, or the deep cultural embeddedness of forms of corruption and cronyism? Because as noted above (Rodrik), such states may need to engage in considerable experimentalism to find the "right" institutions that work for growth and economic and social development, those dimensions of the existing norms (compensation for expropriation and FET or umbrella clause) that lead to compensation for regulatory change (justified of course to an extent under the previous implicit bargain rationale) may make the desired experimentalism more costly and less likely. The rule of law substitute rationale thus supports efforts by some states in recent negotiations of new treaties ${ }^{107}$ and through interpretative understandings of earlier treaties to prevent norms such as FET (or umbrella clauses and a reading of expropriation that extends broadly to regulatory takings) being deployed to protect investors against regulatory change of a kind that is not inconsistent with the rule of law or good governance practice but nevertheless is understood somehow to undermine the investor's legitimate expectations. A robust policy exceptions clause would also be appropriate in the case of the rule of law substitute rationale; in the case of transitioning and underdeveloped countries, which do not reject the rule of law so understood on ideological grounds, but which face financial and other obstacles to duplicating developed country practices that are generally regarded as good governance, a policy exceptions clause provides an opportunity to show that the rule of law shortfalls are better addressed through devoting resources to the improvement of institutions rather than compensating individual investors.

\section{The international justice rationale}

As noted in the historical overview at the beginning of this essay, the first norms of investor protection developed out of diplomatic protection of aliens. Outright discrimination by a host state on account of being an alien is an obligation that accords with a system of international law premised upon equality among states and, as the human rights revolution progresses, peoples and individuals as well. NT combined with a robust public policy exception that allows justified departures from non-discrimination, for example on national security grounds, seems to align well with a notion of

107 For a useful overview, see C. Henckels, Protecting Regulatory Autonomy Through Greater Precision in Investment Treaties: the TPP, CETA, and TTIP, 19 Journal of International Economic Law (2016), 27. 
international justice. But what about FET? Does international justice really require that a state be held to a standard of treatment of aliens superior to the treatment of its own people? If we take a strict or narrow view of the content of FET (as applying to denial of justice, clearly arbitrary legally unfounded treatment of the investor, dishonesty, fraud, and corruption in the regulatory or judicial process) then the normative substance aligns to some significant extent with the international human rights obligations that states have (subject to police powers exceptions) to their own people under major human rights instruments such as the UN Civil and Political Covenant. One could regard FET in the strict or narrow sense (i.e., not read as protecting investor's expectations against regulatory change) as part of a regime for protecting aliens that reflects the values of the international human rights regime. At the same time, the tendency of human rights scholars and tribunals is to read international human rights norms to require that states extend some human rights protections to non-nationals in certain situations. In a recent case of diplomatic espousal decided by the International Court of Justice, Diallo: Republic of Guinea v. Democratic Republic of the Congo, Diallo, a national of Guinea who was an investor in Zaire (Congo), was arrested, jailed without trial for almost 3 months, and then expelled, all on account of his taking steps to collect debts owed to his companies there. For these basic violations of Diallo's human rights, the International Court of Justice awarded him damages of $\$ 95,000 .{ }^{108} \mathrm{Ei}$ ther the intuitions of ICJ judges about international justice are very different than those of investment arbitrators, or the multi-million dollar awards of the latter for less grave wrongs than locking someone up without recourse for months to harass or punish them for exercising their legal rights are about something other than international justice. (The battle over "appropriate" versus "full" compensation discussed in the historical overview was in a sense won by the developed countries, not through a new normative consensus, but in the first instance through the dominance of developed country views in the international legal community, then later the notion that, regardless of justice considerations, such compensation incentivizes investment that is beneficial to the host countries, the instrumental rationale canvassed above.)

It is sometimes suggested that a reason for FET and compensation for expropriation (as opposed to limiting investor rights to NT) is that investors need special protection since they tend to be subject to obstacles in

108 Ahmadou Sadio Diallo, (Republic of Guinea v. Democratic Republic of the Congo) Compensation, Judgment, ICJ Reports 2012, 324. 
the host country that domestic economic actors do not face: for example, they likely have fewer contacts with the political process or elite governing circles in the host country than comparable domestic players, and also they are likely to be affected by subtle forms of bias towards "one's own" or negative stereotypes and misunderstanding concerning what foreigners think and how they are likely to act. Notably however the empirical evidence suggests no disadvantage to firms from foreignness as such (as opposed to protectionism, caught by NT, which involves targeted actions to advantage domestic economic actors over foreign investors in like circumstances). ${ }^{109}$ As discussed above, in the articulation of the international justice rationale, this rationale is weak or questionable when understood in post-Westphalian human rights or humanity law terms, if norms of international justice are not also applied to the conduct of the investor. More generally, there are issues of international justice that are engaged by foreign investment that would dictate the protection of non-state actors other than investors at the international plane, such as workers and indigenous peoples. Given the power that foreign investors have, especially if they are large multinational corporations, it seems perverse that protections at the international plane in the context of investment would privilege them over more vulnerable affected constituencies.

Thus part of the normative universe implied by this rationale is that investors be bound by codes of corporate responsibility, and their own access to international justice is contingent on being subject to it. India's 2016 BIT thus goes farther toward alignment of investor protection with the international justice rationale, in subjecting investors to corporate responsibility, including anti-corruption norms, and making investors' full enjoyment of rights under the treaty contingent on compliance with these obligations.

\section{The anti-protectionism rationale}

Taken together, the fair and equitable treatment and national treatment investment provisions provide a non-discrimination regime for investment that is comparable to that for trade in goods and services in the GATT, where measures that alter competitive opportunities between domestic and imported goods and services, must be justified as necessary, or closely related to some legitimate public policy objective as stated in the excep- 
tions to the GATT or the General Agreement on Trade in Services (GATS), and must not be applied in an arbitrary manner (the chapeau provision of the relevant exceptions as interpreted by the WTO Appellate Body). Article $\mathrm{X}$ of the GATT requires that trade-related regulations be maintained in a transparent manner and applied in accord with the rule of law, and thus there is significant overlap with the notion of fair and equitable treatment. (At the same time, a requirement of compensation for non-discriminatory takings for legitimate public policy purposes and in accordance with the rule of law would not be explicable on an anti-protectionism basis.) Investment protection norms would more closely align with the anti-protectionism rationale if the treaty were to include a robust explicit public policy exception provision, as is the case with GATT and GATS. This would further ensure that NT and FT obligations are not applied so as to require compensation for legitimate public policies just because their economic effects fall disproportionately on foreign firms (while there is no evidence protectionist purpose that can be linked to such consequences). Finally, an antiprotectionism rationale would favour a right of establishment (something that is present in a rather limited manner in the GATS) that would preclude per se exclusion ab initio of foreign firms as competitors through FDI. Some investor protection treaty instruments, especially those where the US is a party contain such a right. Nevertheless, for the reasons already mentioned, one would want the right to establishment to be subject to a robust public policy exceptions clause, as is the case with the GATS.

\section{Matching the Form of Dispute Settlement to the Rationale for Treaty-Based Investor Protection}

I now consider how these alternative rationales for substantive investor protection bear upon the choice of dispute settlement mechanism. Here, in order to relate rationales and substantive norms to the choice of dispute settlement mechanism in a manner that clearly illustrates the complex interactions between rationales, substance, and process, I consider 3 stylized and simplified options: 1) ISDS in its current form, which has the features of party autonomy (parties choose the arbitrators who decide the dispute); typically, exclusion of state-to-state dispute settlement (ICSID requires refraining from diplomatic protection); finality (no appeal but very circumscribed review for bias, etc., either by domestic judges, New York Convention, or an Annulment Committee, ICSID); no precedent, i.e., ad hoc arbitral tribunals don't follow routinely earlier decisions; 2 ) the EU model of a bilateral Investment Court System (ICS) with precedent (a judicial first in- 
stance and an appeals body), strong rule of law norms on conflict of interest, qualifications of arbitrators, compensation of arbitrators primarily through a salary not fee for service, etc., accommodation of state-to-state dispute settlement; ${ }^{110} 3$ ) a multilateral tribunal model that is currently being developed by the International Institute for Sustainable Development (IISD model) that would have many of the "rule of law"/judicial features of the EU ICS model but perhaps also afford the opportunity to stakeholders other than investors to bring claims and/or counterclaims, ${ }^{111}$ and would also facilitate, on one version, state-to-state dispute settlement. It would be expected that a multilateral court would compensate judges through a salary primarily rather than on an hourly fee basis. The EU and Canada are now engaged in discussions with a range of other states on the creation of a multilateral investment court; ${ }^{112}$ whether the Canada-EU multilateral model will facilitate claims by actors other than investors is not yet clear.

110 The basic features of the EU ICS are as follows: 5 judge tribunal of first instance, 5 judges of EU, 5 of US nationality, and 5 of $3^{\text {rd }}$ country nationality. Requirements: judges must be at a minimum "jurists of recognized competence... demonstrated expertise in public international law"; cases heard by divisions of 3 judges; one of EU, one of US, and one of third-country nationality. Divisions appointed by the president of the court, on a rotating, random basis; "judges shall be available at all times and on short notice [...]"; 6 member appellate tribunal, similar qualifications as for first instance, hearing appeals in divisions of 3. Similar diversity of nationality requirements as with first instance; monthly retainer similar to that provided to WTO AB judges; 90 days to file appeal from date of final award; appeals to be decided within 6 months. Extension to 9 months possible with reasoned explanation; transparency based on UNCITRAL rules, but in addition pleadings to be publically available subject to redaction of confidential or protected information; possibility of $3^{\text {rd }}$-party intervention: $3^{\text {rd }}$ party must have "direct and present interest in the result of the dispute"; in addition possibility of submission of amicus briefs by others as well as $3^{\text {rd }}$ parties so defined; appeal based on error of law as well as manifest error in appreciation of the facts; once finalized (either by appellate revision or because no appeal filed after 90 days) award shall be treated by parties as a final award of their judicial system, "not subject to appeal, review, set aside, annulment or any other remedy"; enforcement purposes, award shall be deemed to be arbitral award within meaning of New York Convention or ICSID Convention if applicable; strict conflict of interest rules, code of conduct for both levels: judges must discontinue any counsel work upon appointment (i.e., no "two hats").

111 The possible features of the multilateral tribunal were considered at the IISD Expert Group Meeting held in Lausanne, Switzerland from $23^{\text {rd }}$ to $24^{\text {th }}$ May 2016, entitled 'Investment-related dispute settlement: towards a comprehensive multilateral approach'

112 European Commission \& Government of Canada, supra note 7. 


\section{A. The incentive rationale}

Those who subscribe to this rationale, which is the case with much of the arbitration bar and many of the private sector lobby groups active on this issue, tend to understand treaty protections for foreign investors in terms of the first rationale discussed in this essay: a kind of implicit contract or bargain whereby the host state makes certain promises of economic value, through the device of a treaty, as an inducement or incentive to the investor to invest, or increase its investment. Treaty-based protections are thus seen as analogous to actual investment contracts, common for example in extractive industries, where the government enters directly into contractual relations with the investor in respect of a particular project (mine, dam, etc.). Such contracts are typically enforceable through international arbitration under the same facilities as investor-state arbitration is available under. If dispute settlement under treaty provisions is a response to the problem of incomplete contracts and the hold-up problem specifically, the case for arbitration could be understood as similar to the case of true investment contracts as just described or even international commercial contracts. Especially when the defendant is a state, there are considerable advantages to not being dependent on the defendant's domestic legal system, including the risk of political interference in the enforcement of the contract by domestic legal institutions, or interference with attempts to execute a judgment through the seizure of state assets. If the role of ISDS is to fill gaps or complete the contract ex post, then party autonomy to choose the tribunal, characteristic of the existing system of arbitration, makes particular sense; the aim is not a correct interpretation of legal terms such as fair and equitable treatment that one would expect to be followed generally, but the identification ex post of some events that if the parties could have efficiently specified ex ante they would have determined to trigger liability for compensation. If arbitrators are filling the gaps in an incomplete contract, their focus would understandably be on navigating between the parties' opposite views of whether a particular event could be expected to undermine the bargain. The value of precedent and hierarchy are obviously limited, because the meaning of fair and equitable treatment and compensable takings is anchored not in the normative universe of international law or some general conception of the legitimate dividing line between a hold-up or opportunism on the one hand and justified policy intervention on the other, but whether given the nature of the relationship between the parties and the overall function of treaty protections in providing an incomplete contract for compensation against regulatory change, the particu- 
lar events in question fall within what the parties would have included had they devised ex ante a complete contract to solve the hold-up problem.

Experience with the commercial world range of economic activities undertaken by foreign investors, their structures, and economic basis might be seen as highly relevant, and perhaps the capacity to make "correct" legal interpretations less relevant.

Arbitration allows the investor to choose one of three arbitrators, which is often given by the arbitration bar as an advantage of a permanent international court where the judges would be chosen by member states, as in the EU proposal. This, in theory at least, ensures there is one adjudicator who is likely to be aware of the investor's perspective on the regulatory change as extraction of rents contrary to the legitimate expectations of the investor.

However, if one follows the analysis by Bonnitcha and Aisbett of the hold-up problem, matters are not so straightforward. It will be recalled that under this variation (and even perhaps more generally due to the moral hazard issue with respect to the investor), a robust public policy exception is desirable as a substantive norm (either written in the treaty or adjudicator-created), to ensure that the host state does not have to pay compensation for efficient, non-opportunistic public policies. Under such a norm, the function of the adjudicator veers more towards that of a public law judge deciding on the justification of regulations than a commercial arbitrator filling in the gaps in an incomplete contract. Fundamentally, determining the limits of justified or efficient regulation is an exercise of public authority, in the sense meant by Professors Bogdandy, Goldmann, and Venzke in their important work on the legitimacy of international adjudication. ${ }^{113}$ As Venzke puts it, "international investment tribunals exercise international public authority in the sense that they have the capacity of affecting the freedom of others in pursuance of a common interest [footnote omitted]....decisions [of tribunals] redistribute argumentative burdens and shape expectations, even in the context of decentralized arbitration." 114

113 A. von Bogdandy et al., From Public International to International Public Law: Translating World Public Opinion into International Public Authority, 2 MPIL Research Paper Series (2016).

114 I. Venzke, Investor-State Dispute Settlement in TTIP from the Perspective of a Public Law Theory of International Adjudication, 6 Amsterdam Centre for International Law Research Paper Series (2016). 
Hence, the qualifications and juridical outlook of a public law judge (consonant with the EU ICS model or the IISD multilateral tribunal model) might be more apposite than those of a commercial arbitrator.

An advantage often attributed to arbitration is finality apart from the possibility of an annulment within ICSID or a judicial review under the New York Convention (where in both cases the grounds on which an award may be overturned are quite narrow, and such reversals quite infrequent) arbitral awards cannot be appealed. This is said to reduce costs and uncertainty. The EU bilateral ICS model and the Canada/EU115 \& IISD multilateral tribunal model envisage appeal, and the following of appellate rulings as precedent. On the incomplete contract/hold-up rationale, appeal would be largely wasteful and would not meaningfully operate to improve the outcome of the arbitral tribunal, which has fundamentally the task of a fact-intensive inquiry that entails completely the contract in light of the regulatory change ex post and its effect on the investment. In this case, precedent is less relevant since each set of facts is different in ways that are likely to matter as to whether the kind of regulatory treatment at issue is compensable as host state opportunism; however, the consistency in approach to case-by-case detection of host state opportunism that comes with a permanent bench of judges deciding these matters repeatedly may still be important in reducing the risk of regulatory chill. But where arbitral tribunals are engaging in the exercise of examining the justification of regulations (e.g., their justification as serving domestic welfare as understood by the regulating state), inconsistency in standard of review and juridical understanding of what is entailed in justification (strict necessity, proportionality, or a form of rationality analysis), which are produced by a system of arbitration without precedent and appeals, can lead to a particular form of uncertainty. ${ }^{116}$

115 While many features of the Canada/EU multilateral model remain to be determined in future consultations and deliberations, at a recent stakeholder consultation on the model EU Trade Commissioner Malmstrom noted that one would expect to see appeal in any normal system of legal justice. European Commission, 'Stakeholder Consultation on Multilateral Reform of Investment Dispute Resolution' (2017), available at https:/webcast.ec.europa.eu/stakeholder-meeting -on-a-multilateral-reform-of-investment-dispute-resolution (last visited 6 December 2018).

116 A particularly stark example is the case law on the necessity or public policy justification for measures taken by Argentina to address a national economic crisis; the tribunals veered widely between deference and an almost impossibly strict scrutiny, both under general international law (the necessity provision of the International Law Commission Articles on State Responsibility) and public policy 
This uncertainty is likely to have asymmetrical consequences for the investor and the host state. Extreme uncertainty about whether a tribunal is likely to view the regulatory intervention as justified or not may to some extent address the moral hazard problem with respect to the investor, since the investor doesn't know whether the tribunal will find compensable or not a regulatory intervention that is in some measure due to social costs imposed by the investment that were not observable ex ante.

Such uncertainty may well affect the settlement of claims. An investor has a powerful threat against a host state whenever it has a deep enough pocket to sustain litigation costs even if it loses the claim. It is plausible that uncertainty will not deter firm managers from bringing a claim even if a win is highly uncertain. Generally speaking, litigation to protect the value of the firm should be popular with shareholders; in a system where it is widely understood that there is a huge variance of outcomes and few consistent patterns in awards, it is hard to criticize managers for deciding to litigate, even if eventually they lose and there are high litigation costs.

Moreover, through third party funding, whereby a hedge or vulture fund type entity provides funds for the litigation in return for a share of the award if the claimant is successful, the firm can reallocate part of the risk of an unsuccessful outcome-no damages and high litigation coststo the third party funder; the third party funder, under conditions of high uncertainty about the likely outcome in any particular case, is the better risk bearer than the firm that is a claimant because it holds interests in a diversified portfolio of investment claims. ${ }^{117}$ Third-party funders have no interest in assuming part of the litigation risk of defendant states because there is no prospect of a pay-out even if the state is successful in defending the claim. Managerial blame for an unsuccessful outcome is yet further mitigated by the distinctive feature of arbitration that the investor can appoint one of the arbitrators: that arbitrator might be inclined to pen an extensive dissent in case the investor loses, which in a sense vindicates the

exceptions under the treaties. See J. Alvarez \& T. Brink, Revisiting the Necessity Defense, in K. Sauvant (eds.), Yearbook of International Investment Law and Policy 2010-2011 (2012). These cases are particularly instructive as they dramatically illustrate that in a system without precedent even a broad view of annulment will not lead to consistency, as annulments of the various arbitral awards also led to inconsistent annulment judgments.

117 The question of the effect of third party funding on incentives for settlement is raised but not analyzed in D. Gaukrodger \& K. Gordon, Investor-State Dispute Settlement: A Scoping Paper for the Investment Policy Community, 3OECD Working Papers on International Investment (2012). 
managers' judgment to bring the case in showing that if only one other arbitrator had applied the law or analyzed the facts in the way the dissenter did, the claim would have been successful.

In the case of government agents, refusing settlement and then losing may mean being blamed for a huge pay-out that must be imposed on the taxpayers by the managers' political masters; a dissenting judgment from the government appointed arbitrator may help the firm's managers justify litigation costs in the case of a loss, but are less likely to have a strong effect on the view of a manager who gave up the possibility of a settlement at much lower cost and has now stuck the taxpayers with what might be an exponentially larger bill. Knowing that the firm's agents, the managers, will have strong incentives to litigate if the government does not settle, and that they, the government agents, are taking a high risk if they do not settle with the firm, government agents will often be willing to settle claims, regardless of whether they genuinely believe that the regulation is fully legitimate, justified, efficient. Government agents are less likely to be criticized for settling a non-meritorious case (i.e., rolling back legitimate legislation or making a pay-out where they believe the regulation is justifiable) because it is hard, under asymmetrical information, for the political masters, and even more so for the ultimate principals, the voters/taxpayers, to evaluate the strength of the claim or predict how it might have gone with a tribunal. But where government agents do not settle and there is a huge award, it is very easy to blame them for not having settled. Again, we bear in mind that the agents operate under high uncertainty about how a tribunal will approach justification. In this world of high uncertainty produced by lack of precedent and appeal, the incentives of firm managers and government managers taken together can easily be seen as resulting in regulatory chill, or on the other hand, pay-outs to firms under threat of litigation. There is insufficient scholarly work on settlement of investment claims under threat of litigation and on regulatory chill, though it is often alleged by critics of ISDS. But there is a growing body of anecdotal evidence suggesting that these effects are real. ${ }^{118}$ With the assistance of Juliane Fries, I examined the settlements in the 121 completed investment proceedings identified by UNCTAD as settlements (rather than a win for the investor or the host state). ${ }^{119}$ Of the settlements for which public informa-

118 See K. Tienhaara, Regulatory Chill and the Threat of Arbitration: A View from Political Science, in C. Brown \& K. Miles (eds.), Evolution in Investment Treaty Law and Arbitration (2011), 606.

119 The raw data is presented in an annex to this paper. 
tion was available, almost all appeared to involve either significant monetary relief for the investor (almost always in the multiple millions and in some cases reaching the billions) or significant adjustment of the regulatory framework to the benefit of the investor.

Uncertainty generates not only more claims, for the reasons discussed, but it also generates more work for counsel, who must prepare in their briefs arguments based upon different scenarios as to how the tribunal may interpret the law; in the absence of stare decisis all legal questions must be considered with the depth appropriate to questions of first impression. At the same time, while lacking the guidance of precedent and thus required to invest considerable time in considering what is the "right" approach on basic jurisprudential question, the arbitral tribunal will usually feel it must at least take account of all the prior many non-binding inconsistent arbitral awards. Thus, counsel and arbitrator billable hours are maximized through a system without stare decisis and appeal. It is no wonder that almost none of the "super-arbitrators" for whom arbitration combined with counsel work is a source of considerable personal wealth seems keen on introducing stare decisis and appeal.

An ICS with precedent and appeal will not eliminate all uncertainty about outcomes in a given case; but if there is a sufficiently large and consistent body of precedents, a baseline community judgment of whether a case is strong or weak is likely to emerge. Managers in firms are more likely to be held to account if they pursue to a negative outcome cases that seem outliers against that community judgment; government managers may be faulted or at least questioned if they quickly settle a weak claim rather than defending it, or fail to settle a strong claim, and pursue litigation to a negative outcome.

A multilateral tribunal of the kind being evolved by IISD and the EU and Canada would offer, like the EU ICS, precedent and appeal. The advantage of multilateralism is the greater number of disputes that can be decided in a given time period given the number of countries who are parties to the system; as the WTO dispute settlement system example shows, this can lead to a rather rapid development of a significant body of precedent, stabilizing expectations more quickly than in a system where the universe of possible disputes is limited to disputes between investors from the two parties and those two states (EU investor versus the Canadian state or a Canadian investor against the EU).

In some versions, the IISD evolving model would allow multiple stakeholders including environmental groups and other civil society interests to bring claims or counterclaims. In that case strategic behaviour on the investor side is even better controlled; before deciding to bring a claim the 
investor or its managers must reckon with the risk that if the regulatory intervention is connected to responding to social costs that were unanticipated or unknown to the government ex ante the investment, bringing an action will trigger a claim or counterclaim by other groups in respect of those social costs (assuming that the multilateral tribunal has jurisdiction to adjudicate norms of corporate social responsibility).

In sum, existing features of ISDS like party autonomy (party appointment of arbitrators), an emphasis on repeat players with commercial experience or expertise, and lack of precedent and appeal seem well calibrated with the general incentive rationale for investor protection, at least in its least implausible version that emphasizes the significance of opportunism with incomplete contracts. When we bring in considerations of investor moral hazard, and the rather stronger hold up variant of the implicit bargain rationale, however, the different features of a bilateral ICS or a multilateral tribunal might lead to more optimal outcomes, especially taking into account how very high uncertainty due to absence of precedent and appeal affects incentives to settle, and the chance of pay-outs of unmeritorious claims or regulatory chill, i.e., the investor backing off from justified, efficient regulation.

A further type of uncertainty is also remedied through a single multilateral court-the uncertainty that comes from forum-shopping. A clear example of this is the case of Ron Lauder, an American businessman whose telecommunications venture in the Czech Republic was affected by regulatory changes during the transition period from communism. In order to maximize the chances of recovery, Lauder sued in one forum under his own name and in another in the guise of Dutch corporation, under the Netherlands-Czech Republic BIT. Under the same facts and largely identical legal provisions, Lauder was awarded $\$ 270,000,000$ in damages by the one forum and zero damages in the other. By entering into a multilateral treaty instrument, states parties could vitiate their consent to be subject to arbitration in all others, thus stopping forum-shopping dead in its tracks.

Finally, state-to-state dispute settlement seems ill adapted to the implicit bargain rationale even in its hold-up version. The key to the rationale is understanding investor protection as an implicit bargain to incentivize investment or enhance the impact of other investment incentives in the case of the hold-up variant of the rationale. While the evidence suggests there is in fact no or little incentive effect from treaty-based investor protection, this rationale becomes even less plausible if the investor is dependent on the contingency that the state of which they are a national will bring a claim and then transfer a monetary award to the investor. 


\section{B. The rule of law substitute rationale}

In a Cold War/north-south ideological conflict context, the rule of law rationale might point to the importance of party autonomy. Since ideological differences limit severely the possibility of common ground based upon a shared general perspective on international legal norms and the meaning of good governance and the rule of law, the fact that the adjudicators have been accepted by the parties as trusted to resolve the dispute could be thought to have significant legitimating value. Resolving the dispute is in fact mediating a conflict between ideological adversaries. The fact that arbitrators overwhelming come out of a small Western European centred network would seem irrelevant to legitimacy, if they are the persons who are acceptable to the adversaries. Attempting to achieve a "correct" interpretation of the law could even undermine the depoliticization objective; as such an exercise would easily be viewed by one side or the other of the ideological divide as entrenching a deeply contested understanding of the normative legal universe. Having precedent and appeals would be essentially useless or perhaps even counterproductive. A careful application by trusted persons of very limited treaty commitments to the complex facts is what is wanted here, not a right answer on the meaning of the law in a broader normative universe.

But under other circumstances, the rule of law rationale points to the need for the tribunal to have legitimacy equal to or greater than a court deciding administrative law type disputes that concern the treatment by the state of private actors. The legitimacy of an international tribunal replacing a domestic court is here premised on the international court not possessing similar rule of law pathologies or weaknesses as identified in the host countries. The difficulty is that with respect to conventional investor state arbitration critics have identified the very kind of rule of law weaknesses that international dispute settlement is supposed to respond to and overcome.

Perhaps one of the most egregious ethical lapses in the existing system of investor-state arbitration is the tolerance of arbitrators who at the same time act as counsel in investor-state disputes. ${ }^{120}$ Many ISDS insiders see this as entirely normal and appropriate. How is it that an arbitrator who is in

120 N. Bernasconi-Osterwaler et al., Arbitrator Independence and Impartiality: Examining the Dual Role of Arbitrator and Counsel, Background Paper-International Institute for Sustainable Development, IV Annual Forum for Developing Country Investment Negotiators (2010). 
active practice can avoid being perceived, in the legal interpretation made as an arbitrator, as swayed either consciously or a subconsciously, by wanting to create a jurisprudential universe on balance more rather than less favourable to the clients they continue to represent as counsel in other disputes? The perception of non-impartiality would have to be especially acute where an arbitrator is deciding a specific legal issue in one case knowing that she has another case as counsel where how the very same legal issue is decided has high stakes for their client. On the one hand, one could argue that lack of precedent here helps, as an arbitrator could not in fact be sure that any persuasive weight is given to their decision by another arbitral tribunal, before which the arbitrator has a role as counsel, or may be seeking such a role. On the other hand, lack of precedent means it is easier for any given arbitrator to choose any legal stance in which they have an interest, as they do not have to be accountable in terms of the previous case law.

Further, as the critics have rightly noted, in investor-state arbitration, the pool of adjudicators is a small, self-referential, mutual backscratching clique, more often moved by the prospect of substantial material gains from the justice process than duty or public service-much as one might imagine the legal and judicial world in a state where the rule of law is not well developed. There are no real formal stipulated professional educational qualifications or standards or training for investor-state arbitrators. Basically anyone can be an arbitrator in an investor-state dispute, if one of the parties feels like appointing them. According to the key empirical study of the arbitrator network:

While the international arbitrators' network may share important properties with other social networks, arbitrators, as compared to other judicial groups, are used more instrumentally and are relatively less constrained and (often) less accountable. Unlike judges, arbitration professionals wear different hats, such as counsel, experts, and arbitrators. ... appointments may translate into direct and indirect economic gains ...The network of international arbitration professionals is heavily dependent on a small number of socially prominent actors... ${ }^{121}$

121 S. Puig, Social Capital in the Arbitration Market, 25 European Journal of International Law (2014), 422-423. See also the more recent work J. Alqueres, A BIT of Strategy: Bias and Strategic Formation of Arbitrators' Network at ICSID, New York University Working Papers (2016). 
Finally, on the rule of law substitute rationale, state-to-state dispute settlement does not appear fitting. It seems logical that investors would have direct access to dispute settlement: the investment regime is in fact viewed as a substitute for the rule of law/basic protections of contract and property rights that a private economic actor would "normally" have under conditions of good governance (at least as understood by those who buy into the "Western"/developed world understanding of this, which of course includes most of the developing world governments today, at least in principle).

\section{The international justice rationale}

Investor-state arbitration is not generally understood as being centrally concerned with justice or supporting a just international legal order as opposed to an efficient settlement of a dispute between two parties. As one investor-state arbitral tribunal noted: "The Arbitral Tribunal's mission is ... mundane... to resolve the present dispute between the Parties in a reasoned and persuasive manner, irrespective of the unintended consequences that this Arbitral Tribunal's analysis might have on future disputes in general." ${ }^{122}$ There are many features of investor-state arbitration that are at odds with an essential mission of doing justice, especially as understood in human rights/humanity law terms. As in the EU ICS model (and probably also in the evolving IISD multilateral model), and in stark contrast to traditional ISDS, international courts and tribunals that dispense justice are staffed by judges appointed by a process determined by states parties. This is true of the international criminal tribunals and regional human rights tribunals, such as the Inter-American and European Human Rights Courts as well as the UN human rights institutions that perform a dispute settlement function and receive petitions from non-state actors. Why should a foreign investor, unlike other non-state parties before international courts and tribunals where equally grave matters are at stake, have an entitlement to choose one of their judges and be involved in the appointment process of another?

In addition, given the legacy of long-standing normative controversy and contestation, especially between developed and developing countries about what international justice means or requires in the investment area, the closed insider network aspect of arbitrator appointment discussed 
above raises serious concerns from an international justice perspective. The data disclose that appointments to investor-state arbitral tribunals are overwhelming of male Europeans of middle age or older; the WTO does considerably better in the kinds of diversity - gender, nationality, etc.-that plausibly make a difference to at the least the perception of international justice. ${ }^{123}$

The multilateral tribunal model may align the best of all with the international justice rationale, which implies consistency of justice such that investors would be subject to norms of international justice, not just protected by them. In particular, IISD initiative towards an "inclusive" multilateral approach to investment disputes envisages that civil society and stakeholders in the community could bring claims against either governments or investors or both, under norms of corporate social responsibility, which would be part of the applicable law for the tribunal (while aware of the difficulty that many of these norms have not achieved the status of hard international law). Matters of international justice that relate to foreign investment can hardly on a principled basis be limited to those that affect one (often more powerful than vulnerable) stakeholder-the investor.

\section{The anti-protectionism rationale}

If we take the forth, anti-protectionism rationale, dispute settlement entails the application of a non-discrimination regime with sensitivity to the need to avoid impugning legitimate non-protectionist public policies, even when they may seem to have some negative impact on a foreign investor. The tribunal must evaluate non-protectionist justifications for the measures in question, and perhaps weigh these against the degree of restrictiveness of or scale of impact on foreign investment. In effect, the tribunal is determining the limits of legitimate regulation, and therewith of democratic sovereignty or regulatory autonomy imposed by the international legal regime. This seems very clearly an exercise of international public authority that points to a judicial model for the settlement of disputes. At the same time, as is exemplified by the WTO, it hardly necessarily points to investor-state, as opposed to state-to-state dispute settlement. While there is a very extensive economics literature on dispute settlement in international

123 J. Pauwelyn, The Rule of Law Without the Rule of Lawyers: Why Investment Arbitrators Are From Mars and Trade Adjudicators from Venus, 109 American Journal of International Law (2015), 761. 
trade, I am not aware of any significant economic analysis that contends that direct access for private parties to dispute settlement is required to perform the economic function of anti-protectionism legal norms as exemplified by the WTO non-discrimination regime. The one scholar who has most insistently argued for access of private parties to dispute settlement under WTO norms, Ernst-Ulrich Petersmann, has done so out of a (libertarian) human rights-based understanding of anti-protection norms, something akin to the international justice rationale discussed in this paper; and Petersmann notably has articulated this in terms of access to domestic courts for enforcement of WTO norms. ${ }^{124}$

The experience of the WTO system for trade indicates that it may take some time and a significant number of cases before a relatively stable jurisprudence can develop; a durable jurisprudence constante is more likely to emerge from a multilateral tribunal where the set of possible disputing parties is larger than a bilateral model. As Anthea Roberts has shown, there is no inherent incompatibility that would prevent the co-existence of state-to-state and investor-state dispute settlement, although there may be issues of overlapping claims, double remedies and so forth that need to be resolved. ${ }^{125}$

Attempting to address general discriminatory barriers to investment that are analogous to the kinds of trade barriers already disciplined under GATT/WTO rules through offering a private right of action to individual investors may well be inefficient, resulting in sub-optimal enforcement. Many economic actors stand to benefit from the removal or adjustment of such barriers. The characteristic remedy in investor-state arbitration is a monetary payment to a single investor claimant; a settlement will either be a monetary payment or if there is a regulatory adjustment it is usually one that is a special regulatory side-payment to the particular investor who has brought claim. The investor and their counsel have the incentive to frame their claim not in terms of the community interest in the removal of inefficient discriminatory protectionism but to maximize advantage for that particular investor. State-to-state dispute settlement under a bilateral court system model, while superior to investor-state in the sense that the state can represent a broader set of interests in the removal of protective discrimina-

124 E.U. Petersmann, Justice in International Economic Law? From the 'International Law Among States' to 'International Integration Law' and 'Constitutional Law', 46 European University Institute Working Papers LAW (2006).

125 A. Roberts, State-to-State Investment Treaty Arbitration: A Hybrid Theory of Interdependent Rights and Shared Interpretive Authority, 55 Harvard International Law Journal (2014), 1. 
tion, is still suboptimal to proceedings in a multilateral investment court, where it is possible for a range of states (and perhaps other interests) who stand to gain from the elimination of discriminatory barriers to investment to join a common action, where the state, if found to be in violation of non-discrimination norms and unable to justify its measures based on a robust public policy exception, would be ordered to remove the measures, a monetary penalty only being imposed if it fails to do so. Such a common action would involve the sharing of the litigation costs among numerous interested parties from different countries and similarly a remedy that benefits all.

\section{Conclusion}

There is no general sound economic case for compensating private economic actors for regulatory change. Still there is a plausible argument that treaty protection can induce FDI by protecting the investor against the "hold-up" situation where the host state, once the investor has sunk considerable costs into asset-specific investments, extracts rents from the investor ex post through regulatory change. Because of the prohibitive transaction costs of writing complete contracts, it is largely impossible to foresee in a contract ex ante every possible regulatory intervention that might be used to "hold up" the investor ex post. Yet it is unclear why treaty protection is indispensable to solving the hold-up problem. A contractual solution may be superior in many instances as the host state can target the protection to investors that it desires to attract; contracts can themselves deal with the incomplete contract problem by including not only fully specified commitments with regard to regulatory change but also general standards typical of investment treaties (e.g., fair and equitable treatment) which the adjudicator is delegated the role of applying on a case-by-case basis. But, whether under contract or under treaty protection, there is a significant downside risk for host states of investment protection, regulatory chill, and liability for legitimate regulatory interventions, unless the adjudicator is able to distinguish in a coherent and consistent way between hold-up situations on the one hand, and legitimate regulatory interventions not driven by rentseeking on the other. Unless investment treaties contain robust public policy exceptions and are interpreted and applied in the manner of a public law court, sensitive to the challenges of public law and the political preferences of host states, the dangers of regulatory chill and liability for needed regulatory changes should make states think twice about investment treaties and ISDS. 
A rationale for investment treaties that is much less prominently discussed is anti-protectionism. This rationale seems relatively robustly supported by the extension of standard trade theory in economics to FDI under conditions where global supply chains operate through the interdependence of trade (external contracting) and FDI (internal contracting). Discriminatory protective measures on investment reduce domestic and global welfare in the same ways as discriminatory protective measures with respect to trade, misallocating resources, and resulting in higher prices to consumers. But this rationale for investment protection points in the direction not of ISDS but a non-discrimination regime with robust public policy exceptions to cover cases where there is some market failure or overriding moral political concern that would justify discrimination, enforced largely through state-to-state dispute settlement, ideally in a multilateral forum.

Arbitration of investment disputes was originally understood on a rule of law substitute rationale to have the advantage of depoliticizing disputes between "Western" investors and their governments and countries ideologically opposed to the protection of contractual and property rights and direct access to justice for capital in their domestic systems. With the end of communism and the widespread transition to liberal democracy in many places, this rationale is of at most residual significance. Using investment protection norms as a substitute for rule of law more generally, i.e., in cases where there are weak governance and legal institutions in developing or transitional countries, does not get around the fact that what is needed for development is stronger institutions, and indeed by allowing a country access to foreign capital despite weak institutions, may decrease pressures for desirable reforms. In any case, the significant rule of law weaknesses that critics of ISDS have identified with the current system of arbitration (cliquishness, lack of full transparency, tolerance of conflict of interest, lack of consistency in awards fuelled by absence of precedent) make it particularly problematic to assert investor-state arbitration as superior to domestic rule of law in developing or transitional economies. To the extent that ISDS performs a positive function in substituting for domestic rule of law weaknesses, the EU ICS model and the IISD \& Canada/EU multilateral models are much better aligned to this rationale, having much stronger rule of law properties. International justice in a post-Westphalian human rights/humanity law world would imply that investors would have some entitlement under international law to just treatment, but the institutions for international justice would seem unfair if they did not also require that the investor meet some standards of international justice (reflected in codes of corporate responsibility for example), and provide redress not on- 
ly for investors but other stakeholders where international justice is violated in the context of foreign investment. A multilateral court system is best suited to offering standing or intervention to a wide range of actors who have concerns of international justice that relate to foreign investment.

\section{ANNEX}

\section{PUBLICALLY AVAILABLE DATA CONCERNING SETTLEMENTS OF INVESTMENT CLAIMS UNDER TREATIES (Prepared by Juliane Fries)}

1. ArcelorMittal v. Egypt: No information found.

2. Nabucco v. Turkey: No information found.

3. Orange SA v. Jordan: No information found.

4. Paz Holdings v. Bolivia: 19.51 million USD awarded through settlement but no further information (http://investmentpolicyhub.unctad. org/ISDS/Details/689).

5. Iberdrola v. Bolivia: 34.18 million USD awarded through settlement but no further information (http://investmentpolicyhub.unctad.org/IS DS/Details/662).

6. IBT Group and others v. Panama: No information found.

7. Longyear v. Canada: No information found.

8. Red Eléctrica v. Bolivia: 36.50 million USD awarded through settlement but no further information (http://www.sandiegouniontribune. com/hoy-san-diego/ http://investmentpolicyhub.unctad.org/ISDS/Deta ils/583).

9. Al Sharif v. Egypt (I): No information found.

10. Al Sharif v. Egypt (II): No information found.

11. Al Sharif v. Egypt (III): No information found.

12. ASA v. Egypt: No information found.

13. Bryn Services v. Latvia: No information found.

14. ČEZ v. Albania: 100.00 million EUR (136.00 million USD) awarded through settlement but no further information (http://investmentpoli cyhub.unctad.org/ISDS/Details/522).

15. Consolidated Exploration v. Kyrgyzstan: No information found.

16. Isolux v. Peru: Award containing the settlement agreement is available here: http://www.italaw.com/sites/default/files/case-documents/italaw 3130.pdf.

17. OTH v. Algeria: Non-pecuniary relief was provided in the settlement (http://investmentpolicyhub.unctad.org/ISDS/Details/460), but no further information is available. 
18. Repsol v. Argentina: 5000.00 million USD awarded through settlement (http://investmentpolicyhub.unctad.org/ISDS/Details/490). The settlement agreement is available here: http://www.italaw.com/sites/de fault/files/case-documents/italaw3166.pdf.

19. Sanum Investments v. Laos: Non-pecuniary relief awarded through settlement but no further information (http://investmentpolicyhub.u nctad.org/ISDS/Details/489).

20. Slovak Gas v. Slovakia: Non-pecuniary relief awarded through settlement (http://investmentpolicyhub.unctad.org/ISDS/Details/497). The settlement agreement is available here: http://www.italaw.com/sites/de fault/files/case-documents/italaw1369.pdf.

21. Bawabet v. Egypt: No information found.

22. Ekran v. China: No information found.

23. Indorama v. Egypt: 54.00 million USD awarded through settlement but no further information (http://investmentpolicyhub.unctad.org/IS DS/Details/406).

24. Loutraki v. Serbia: No information found.

25. MTS v. Turkmenistan: Non-pecuniary relief awarded through settlement (http://investmentpolicyhub.unctad.org/ISDS/Details/404), which seems to consist of an agreement with the government for a three-year contract to operate in the state, under which it will pay TurkmenTelecom 30 per cent of its net profit per month (http://global arbitrationreview.com/article/1031653/turkmenistan-settles-cluster-oftelecoms-claims).

26. Sajwani v. Egypt: The settlement seemed to consist partly of a reinstatement of land to the Egypt (http://www.reuters.com/article/egyptdamac-idUSL6N0DW 4PL20130515), a waiver by DAMAC of its $17.78 \%$ stake $(80,000$ shares) in Hyde Park in favour of the government agency NUCA, a purchase by NUCA of $3.1 \%$ of the shares owned by the Housing and Development Bank (13,950 shares), which results in a $20.88 \%$ ownership of Hyde Park's shares (93.950 shares) (http://www.dailynewsegypt.com/2015/03/13/disputes-with-investors-g overnment-attempts-to-turn-a-new-leaf/).

27. Shortt v. Venezuela: No information found.

28. St. Marys v. Canada: Consent award adopting the settlement agreement is available here: http://www.italaw.com/sites/default/files/case-d ocuments/italaw1391.pdf. In the settlement, the claimant withdrew all claims against Canada, Canada agreed not to claim costs incurred (http://www.volterrafietta.com/settlement-agreement-reached-in-naftadispute-with-the-government-of-canada/).

29. TPAO v. Kazakhstan: No information found. 
30. Williams Companies v. Venezuela: Payment of $\$ 420$ million by Venezuela for the 2009 nationalization of assets (http://www.reuters.c om/article/us-venezuela-oil-nationalizations-idUSBRE82N0BW201203 24), see also http://www.laht.com/article.asp?CategoryId=10717\&Artic leId $=554563$.

31. AbitibiBowater v. Canada: 130.00 million CAD (123.00 million USD) awarded to the claimant through settlement (http://investmentpolicyh ub.unctad.org/ISDS/Details/374, http://www.theglobeandmail.com/re port-on-business/ottawa-pays-abitibibowater-130-million-for-expropria tion/article1378193/), the consent award is available here: http://www. international.gc.ca/trade-agreements-accords-commerciaux/assets/pdfs /disp-diff/abitibi-03.pdf.

32. Oiltanking v. Bolivia: 16.40 million USD awarded through settlement (http://investmentpolicyhub.unctad.org/ISDS/Details/369, see also http://globalarbitrationreview.com/article/1029948/bolivia-settles-oil-c laim-seeks-counsel).

33. Pan American v. Bolivia: 357.00 million USD awarded through settlement (http://investmentpolicyhub.unctad.org/ISDS/Details/385, https: //www.wsj.com/articles/bolivia-pan-american-energy-reach-accord-140 8724484, http://in.reuters.com/article/bolivia-energy-idINL1N0U21Z C20141218).

34. Universal Compression v. Venezuela: 442.00 million USD awarded through settlement (http://investmentpolicyhub.unctad.org/ISDS/Det ails/392, http://globalarbitrationreview.com/article/1031534/venezuela -settles-icsid-case, http://www.laht.com/article.asp?CategoryId=10717 \&ArticleId=554563).

35. Dow AgroSciences v. Canada: Non-pecuniary relief through settlement (http://investmentpolicyhub.unctad.org/ISDS/Details/345): "claimant withdrew its arbitration request without any compensation, monetary or otherwise, and acknowledged that the disputed measures would remain in force. The settlement also contains an acknowledgement from the Government of Quebec that products containing 2,4-D do not pose an unacceptable risk to human health or the environment provided that the instructions on their label are followed, as concluded by Health Canada's Pest Management Regulatory Agency in its May 16, 2008 reassessment decision. Finally, the settlement agreement also contains an acknowledgement from the claimant that Canada's provinces, territories and municipalities may regulate the sale, use, transportation, and disposal of pesticides in their jurisdictions." (http:/ /www.international.gc.ca/trade-agreements-accords-commerciaux/topi cs-domaines/disp-diff/agrosciences.aspx?lang=eng). The settlement 
agreement can be found here: http://www.international.gc.ca/trade-ag reements-accords-commerciaux/assets/pdfs/disp-diff/dow-03.pdf.

36. Dunkeld v. Belize (I): "Under a September 2015 settlement between the parties, Belize admitted it had expropriated Dunkeld's interest in the Telemedia shares and agreed to withdraw its preliminary objections to jurisdiction, leaving the tribunal tasked just with determining exactly how much Dunkeld was owed." (https://www.law360.com/arti cles/853277/belize-hit-with-171 m-award-for-acquisition-of-telecom-co), see also section "settlement" of the final award: http://www.italaw.co $\mathrm{m} / \mathrm{sites} /$ default/files/case-documents/italaw7669_0.pdf.

37. ETI v. Bolivia (II): Diverging information announcing 50.00 million USD or $100 \mathrm{~m}$ USD awarded through settlement (http://investmentpol icyhub.unctad.org/ISDS/Details/349, http://globalarbitrationreview.co $\mathrm{m} /$ article/1029756/telecom-italia-wins-payout-from-bolivia).

38. EVN v. Macedonia: The award embodying the settlement is available here: http://www.italaw.com/sites/default/files/case-documents/ita031 3.pdf. See also: http://globalarbitrationreview.com/article/1030451/ectclaim-against-macedonia-settles.

39. Holcim v. Venezuela: US $\$ 650$ million awarded through settlement (http:/globalarbitrationreview.com/article/1029601/holcim-and-venez uela-settlement-no-surprise).

40. Itera v. Georgia (II): No information found.

41. Mærsk v. Algeria: "The settlement, based on reciprocal concessions, provides for delivery to Maersk Oil of additional crude oil volumes in the amount of approximately USD 920 million over a period of 12 months from the effective date." (http://www.maerskoil.com/media/ne wsroom/pages/maerskoilsettlesalgeriantaxclaims.aspx).

42. MTN v. Yemen: No information found.

43. Vattenfall v. Germany (I): Settlement agreement available here: http:// www.italaw.com/sites/default/files/case-documents/ita0890.pdf.

44. AEI v. Bolivia: Estimated US\$121 million were awarded through settlement (http://globalarbitrationreview.com/article/1027141/aei-and-b olivia-settle-arbitration).

45. CEMEX v. Venezuela: US\$600 million awarded through settlement: "Under the deal, announced on 1 December, Cemex will receive US $\$ 240$ million in cash and US\$360 million in various negotiable securities issued by state oil company PDVSA. The agreement also provides for the cancellation of intra-company debts, including US\$154 million owed by Cemex subsidiaries to the expropriated unit, Cemex Venezuela." (http:/globalarbitrationreview.com/article/1030826/cemex -settles-with-venezuela). 
46. Impregilo v. Argentina (II): No information found.

47. iZee v. Georgia: No information found.

48. Millicom v. Senegal: "Under this agreement, the validity of Millicom's Senegal subsidiary's license will be recognised by both parties. In addition, Millicom will be granted a $3 \mathrm{G}$ license, an alignment of its license terms with those of the other operators (meaning that Millicom will receive licenses to offer fixed line, WiMAX and cable TV services for instance), some additional spectrum and a 10-year extension of the term of its current license until 2028. Millicom has agreed to pay USD103 million for these additional license rights and spectrum. The USD103 million will be paid in several installments between closing of the agreement and December 2013." (http://www.cellular-news.co $\mathrm{m} / \mathrm{story} / 56096 . p h p$, cf. also http://www.commsmea.com/12581-millic om-settles-licence-dispute-in-senegal/).

49. Abaclat and others v. Argentina: The settlement agreement is available here: http://www.italaw.com/sites/default/files/case-documents/italaw 8023.pdf.

50. ALAS International v. Bosnia and Herzegovina: No information found.

51. Bureau Veritas v. Paraguay: No information found.

52. Eni Dación v. Venezuela: 700.00 million USD awarded through settlement (http://investmentpolicyhub.unctad.org/ISDS/Details/265, https: //www.law360.com/articles/47552/venezuela-reaches-700m-settlementwith-eni).

53. ETI v. Bolivia (I): Diverging information regarding the amount awarded. 50.00 million USD (http://investmentpolicyhub.unctad.org/ISDS/ Details/272) or 100 million USD (http://globalarbitrationreview.com/ article/1029756/telecom-italia-wins-payout-from-bolivia) awarded through settlement.

54. Global Gold Mining v. Armenia: No information found.

55. Laskaridis Shipping v. Ukraine: No information found.

56. Société Générale v. Dominican Republic: 26.50 million USD awarded through settlement but no further information (http://investmentpoli cyhub.unctad.org/ISDS/Details/250, cf. also https://www.iareporter.co $\mathrm{m} /$ articles/dominican-republic-settles-trio-of-electricity-arbitrations/).

57. TCW v. Dominican Republic: 26.50 million USD awarded through settlement but no further information (http://investmentpolicyhub.u nctad.org/ISDS/Details/254).

58. Trans-Global v. Jordan: The settlement agreement incorporated in the consent award is available here: http://www.italaw.com/sites/default/fi les/case-documents/ita0873.pdf. 
59. Barmek v. Azerbaijan: No information found.

60. Oxus Gold v. Kyrgyzstan: No information found.

61. Rail World v. Estonia: 200.00 million USD awarded through settlement (http://globalarbitrationreview.com/article/1025929/estonia-end s-railway-dispute).

62. Shell v. Nicaragua: “...in November 2006, a Nicaraguan court reversed the earlier embargo order. With the trademarks released, the two Shell companies dropped their ICSID claim.” (http://www.iisd.org/pdf/2007 /itn_may9_2007.pdf, p.10).

63. Técnicas Reunidas v. Ecuador: No information found.

64. Vivendi v. Poland: No information found.

65. CGE v. Argentina: "CGE withdrew claims related to electricity distribution concessions in the Argentine provinces of Tucuman and San Juan, following agreement which will see increases in the tariffs which may be charged to electricity customers by the Chilean firm." (http:// www.iisd.org/pdf/2008/itn_april1_2008.pdf, p.5).

66. K+ VP v. Czech Republic: No information found.

67. Mittal v. Czech Republic: No information found.

68. Noble Energy v. Ecuador: 70.00 million USD awarded through settlement (http://globalarbitrationreview.com/article/1027229/noble-and-e cuador-settle-as-port-dispute-looms).

69. Scotiabank v. Argentina: “...Scotiabank Quilmes will receive compensation from Argentina's Central Bank for losses arising from the forced pesification of its US-dollar assets and liabilities in 2002. At the same time the Central Bank has agreed to return assets that Scotiabank had pledged as collateral in return for liquidity support during the crisis." (http:/globalarbitrationreview.com/article/1030505/scotiab ank-drops-ususd600-million-argentina-claim).

70. ABN Amro v. India: Non-pecuniary relief through the settlement (http://investmentpolicyhub.unctad.org/ISDS/Details/149) but no further information. Potentially relevant: https://www.telegraphindia. com/1050721/asp/business/story_5015896.asp.

71. Alstom Power v. MongoliaAlstom Power v. Mongolia: No information found

72. ANZEF v. India: Non-pecuniary relief through settlement but no further information (http://investmentpolicyhub.unctad.org/ISDS/Detail s/151).

73. BNP Paribas v. India: Non-pecuniary relief through settlement (http:// investmentpolicyhub.unctad.org/ISDS/Details/147) but no further information available.

74. BP v. Argentina: No information found. 
75. Cemex v. Indonesia: 337.00 million USD awarded through settlement (http://globalarbitrationreview.com/article/1025755/cemex-to-end-icsi d-claim-against-indonesia, https://www.aggregateresearch.com/news/c emex-agrees-to-cancel-arbitration-case-over-semen-gresik-indonesian-of ficial/).

76. CIT Group v. Argentina: No information found.

77. Credit Lyonnais v. India: Non-pecuniary relief through settlement but no further information (http://investmentpolicyhub.unctad.org/ISDS/ Details/148).

78. Credit Suisse v. India: Non-pecuniary relief through settlement but no further information (http://investmentpolicyhub.unctad.org/ISDS/De tails/150).

79. Erste Bank v. India: Non-pecuniary relief through settlement (http://in vestmentpolicyhub.unctad.org/ISDS/Details/141) but no further information.

80. France Telecom v. Argentina: No information found.

81. Interbrew v. Slovenia 70.70 million USD seem to have been paid (http://investmentpolicyhub.unctad.org/ISDS/Details/144), however, the broader background seems to be the following: "In February of this year [2005] InBev glimpsed a path out of this warren of litigation, by agreeing to sell its minority stake in Union to its Slovenian competitor, Laska, for 70 million euros. As a part of the sale, Laska paid a 3.5 million euro "withdrawal fee" in return for InBev's agreement to terminate all pending local and international litigation relating to the contested brewery. The sale price agreed by InBev with Laska was sufficient to obviate the need for the Dutch firm to pursue its arbitration with the Slovenian Government at ICSID. That claim was formally terminated by order of the arbitration tribunal in late July of this year." (http://www.iisd.org/pdf/2005/investment_investsd_sept6_2005. pdf, p.8).

82. Motorola v. Turkey: “...according to the terms of a settlement agreement reached by Turkey and Motorola, and announced on October 28, the US firm will drop this BIT claim against Turkey. A press release issued by the company reads in part: "Under the agreement, Motorola has settled its claims for a cash payment of $\$ 500$ million which the company received today plus the right to receive $20 \%$ of the proceeds from the sale of Telsim assets over $\$ 2.5$ billion. Motorola has further agreed to dismiss its litigation against Telsim as well as Motorola's pending demand for arbitration against the Government of Turkey at the International Center for the Settlement of Investment Disputes (ICSID) in Washington, D.C. In addition, Motorola has agreed not to 
pursue collection efforts against certain corporate defendants under TMSF control, subject to certain conditions. The agreement permits Motorola to continue its efforts, except in Turkey and certain other agreed upon countries, to enforce its previous judgment rendered on behalf of Motorola against the Uzan family for perpetrating a massive fraud against Motorola through their control of Telsim."” (http://www. iisd.org/pdf/2005/investment_investsd_nov 2_2005.pdf, p.5).

83. Offshore Power v. India: Non-pecuniary relief through settlement but no further information available (http://investmentpolicyhub.unctad. org/ISDS/Details/139).

84. RGA v. Argentina: No information found.

85. Standard Chartered Bank v. India: Non-pecuniary relief but no further information (http://investmentpolicyhub.unctad.org/ISDS/Details/15 2).

86. Tembec v. USA: Claim apparently withdrawn as part of the CanadaUS Softwood Lumber Agreement 2006 (http://iiapp.org/media/uploa ds/canfor_tembec_terminal_v_united_states.rev.pdf).

87. Terminal Forest v. USA: Claim apparently withdrawn as part of the Canada-US Softwood Lumber Agreement 2006 (http://iiapp.org/medi a/uploads/canfor_tembec_terminal_v_united_states.rev.pdf).

88. Trinh Vinh v. Vietnam: No information found.

89. Western NIS v. Ukraine: No information found.

90. Aguas Cordobesas v. Argentina: No information found.

91. Bechtel v. India: 160.00 million USD awarded through settlement (http:/www.bechtel.com/newsroom/releases/2005/07/statement-becht el-dabhol-settlement/).

92. Camuzzi v. Argentina (II): No information found.

93. Ed. Züblin v. Saudi Arabia: No information found.

94. Eureko v. Poland: 12750.00 million PLN (4379.00 million USD) awarded through settlement (http://investmentpolicyhub.unctad.org/I SDS/Details/124). The broader arrangement may have been the following: "Under the agreement, Eureko will be paid more than USD 6 billion. In return for this payout, the deal sets up a government-controlled process for selling Eureko's shares. The agreement sets a deadline of the end of 2011 for all sales of Eureko's holdings in PZU, although this can be extended for a year "in the event of an unsatisfactory price", according to a joint press statement. The deal also precludes Eureko from competing against PZU for three years, as from the date its shareholding in PZU amounts to less than a 13\%. Eureko is also prohibited from buying shares in PZU during and after the IPO for a period of 16 years, unless its stake falls below 5\%, at which point it 
can buy shares as long as its stake stays below the 5\% ownership level. The agreement also requires Eureko and Poland to end the investment treaty arbitration proceedings, and Eureko must waive all other past claims against the government. The arbitral tribunal had produced a majority decision on liability in August 2005 that found Poland to have breached its obligations under the Netherlands-Poland bilateral investment treaty. After failed attempts by Poland in the Brussels courts to set aside the decision and to challenge one of the arbitrators in 2006-2007, the arbitration was set to resume to consider the amount of damages to be awarded to Eureko when the parties instead entered into settlement discussions." (http://uk.practicallaw.com/6-500 -6640 ? service $=$ arbitration).

95. Impregilo v. Pakistan (II): No information found.

96. Miminco v. Congo: 13.00 million USD awarded through settlement (http://investmentpolicyhub.unctad.org/ISDS/Details/112, cf. https:// www.wikileaks.org/plusd/cables/10KINSHASA22_a.html).

97. Pan American v. Argentina: No information found.

98. Pioneer v. Argentina: No information found.

99. Telefónica v. Argentina: No information found.

100. Telekom Malaysia v. Ghana: Payments will take place in instalments over two years (https:/www.modernghana.com/news/77357/1/govt-an d-telekom-malaysia-settle-dispute.html, https://www.telegeography.co $\mathrm{m} /$ products/commsupdate/articles/2005/05/09/state-and-telekom-mala ysia-settle-ghana-telecom-dispute/, http:/www.cn-c114.net/582/a30614 5.html), the sum awarded may be $\$ 50$ million (http://www.ghanaweb. com/GhanaHomePage/NewsArchive/Ghana-Telekom-Malaysia-disput e-settled-81010, http://allafrica.com/stories/200404020392.html).

101. Aguas del Tunari v. Bolivia: No compensation but public declaration that the withdrawal was related to a state of emergency and not to any conduct of the international shareholders of the claimants (http://ww w.bechtel.com/newsroom/releases/2006/01/cochabamba-water-dispute -settled/), a token of \$ USD 30 may have been paid for the claimants to drop the case (see http://democracyctr.org/bolivia/investigations/bo livia-investigations-the-water-revolt/bechtel-vs-bolivia-details-of-the-cas e-and-the-campaign/).

102. Canfor v. USA: Claims withdrawn as part of the US Canada Softwood Lumber Agreement (http://iiapp.org/media/uploads/canfor_tembec_t erminal_v_united_states.rev.pdf) a part of which concerning Canfor can be found here: https://www.state.gov/documents/organization/10 7267.pdf. 
103. IBM v. Ecuador: 3.50 million USD awarded through settlement (http:/ /investmentpolicyhub.unctad.org/ISDS/Details/94). The award containing the settlement agreement can be found here: http://www.itala w.com/sites/default/files/case-documents/italaw4304.pdf.JacobsGibb v. Jordan: No information found.

104. SGS v. Philippines: No information found.

105. AES v. Hungary (I): No information found.

106. Booker v. Guyana: No information found.

107. Saluka v. Czech Republic: Agreement to cap potential damages which the tribunal can award at \$335 million and agreement of the Czech Republic to drop counter-arbitration against Nomura (https://books.g oogle.ch/books?id=IAfb_1jKd1oC\&pg=PA188\&lpg=PA188\&dq=saluk $\mathrm{a}+\mathrm{czech}+$ republic + settlement\&source $=$ bl\&ots=Nr 2pph_660\&sig=AtT d5utCZrtXsmIqTzDP_Pl27Xg\&hl=en\&sa=X\&ei=zpBgVLGtKNPXatn ogvAE\&ved=0CCkQ6AEwAg\#v=onepage\&q=saluka\%20czech\%20rep ublic\%20settlement\&f=false).

108. SGS v. Pakistan: No information found.

109. Salini v. Morocco: No information found.

110. Sancheti v. Germany: No information found.

111. UK Bank v. Russia: No information found.

112. Alimenta S.A. v. Gambia: 11.20 million USD awarded through settlement (http://investmentpolicyhub.unctad.org/ISDS/Details/31, see also https:/www.state.gov/e/eb/rls/othr/ics/2011/157281.htm).

113. Compagnie Minière v. Peru: No information found.

114. Lemire v. Ukraine (I): Award embodying the settlement can be found here: http://www.italaw.com/sites/default/files/case-documents/ita045 2.pdf.

115. Ethyl v. Canada: 13.00 million USD awarded through settlement (http://pubs.acs.org/doi/abs/10.1021/cen-v 076n030.p013a, http://inves tmentpolicyhub.unctad.org/ISDS/Details/16, http://www.cela.ca/articl e/international-trade-agreements-commentary/how-canada-became-shi ll-ethyl-corp). "Canadian federal-provincial dispute settlement panel found that the federal measure was inconsistent with certain provisions of that Agreement. Following this decision, Canada and Ethyl settled all outstanding matters, including the Chapter Eleven claim." (http://www.international.gc.ca/trade-agreements-accords-commercia ux/topics-domaines/disp-diff/ethyl.aspx?lang=eng).

116. Ameritech v. Poland: No information found.

117. France Telecom v. Poland: No information found.

118. Goetz v. Burundi (I): 3.00 million USD awarded through settlement (http://investmentpolicyhub.unctad.org/ISDS/Details/5). The settle- 
ment agreement embodied in an award can be found here: http://ww w.italaw.com/sites/default/files/case-documents/ita0380.pdf.

119. Leaf Tobacco v. Albania: No information found.

120. Gruslin v. Malaysia (I): No information found. 
